\title{
Dehesas as high nature value farming systems: a social-ecological synthesis of drivers, pressures, state, impacts, and responses
}

\author{
$\underline{\text { Tobias Plieninger }}^{1,2}, \underline{\text { Lukas Flinzberger }}^{1}$, Maria Hetman $^{2}, \underline{\text { Imke Horstmannshoff }}^{2}$, Marilena Reinhard-Kolempas $^{2}$, Emmeline Topp $^{2}$, \\ Gerardo Moreno $^{3}$ and Lynn Huntsinger ${ }^{4}$
}

\begin{abstract}
Dehesas and montados are Mediterranean agroforestry systems characterized by scattered oak trees with an understory grazed extensively by livestock and, in some cases, periodically cropped. A long history of traditional management practices has created an open woodland widely recognized for rich biodiversity and multiple ecosystem services. Concerns about challenges to their longterm viability have motivated many disparate scientific studies in recent decades. We provide a synthesis of this growing body of international literature, focusing on the links between land use and management practices, biodiversity, and policy, from a "high nature value farming systems" perspective. The present review comprises 128 empirical studies carried out in Spain and Portugal. Conservation trends were assessed according to categories adapted from the DPSIR (Drivers - Pressures - State - Impacts - Responses) framework. Socio-cultural factors, economic dynamics, and agricultural policies were found to be key drivers of change, resulting in intensification of livestock production and land use simplification, among other effects. Insufficient tree regeneration and a broad range of other factors were identified as pressures that have often negative impacts on biodiversity and ecosystem services, moving the system away from its archetypical ecological state. A variety of management and policy responses were suggested, ranging from specific conservation techniques to landscape-level initiatives. Ecosystem components and management practices were typically studied separately, and mainly from an ecological science perspective, while inter- and transdisciplinary approaches including examination of the role of people were less common. This points to a need to move from single-topic to landscape-level approaches with a broader integration of different disciplines and perspectives.
\end{abstract}

Key Words: agricultural landscapes; agroforestry; Common Agricultural Policy; DPSIR framework; HNV farming; montados; silvopastoral systems

\section{INTRODUCTION}

Worldwide, but notably in densely settled Europe with its long agricultural history, a substantial part of biodiversity depends on farming systems of "high nature value" (HNV farming systems) that comprise multiple grassland, woodland, and cropland types (Strohbach et al. 2015, Moran et al. 2021). HNV farming systems frequently go hand in hand with a deep-rooted history of land use and practices that have shaped and maintained semi-natural habitats of exceptional biodiversity (Raatikainen and Barron 2017, Palacín and Alonso 2018). One such system commonly considered to be HNV farming is the oak-based agroforestry of the Iberian Peninsula, known as dehesas in Spain and montados in Portugal (Pinto-Correia et al. 2018).

HNV farming systems are joint production or land-sharing systems, simultaneously providing two fundamentally different kinds of goods: market goods such as feed, food, and fiber, and non-market ecosystem services of value to society, such as biodiversity or scenery (Wossink and Swinton 2007). Because they are mostly restricted to lands with natural, social, or economic constraints to agricultural production (Lomba et al. 2020, Moran et al. 2021), high nature value farming enterprises often cannot compete with more intensive systems. In addition, most of the value of the public goods provided is difficult for the landowner to capture. As a consequence, many farmers across the European Union are under pressure to either intensify or abandon high nature value farming practices and systems, including dehesas and montados (Plieninger and Bieling 2013). Societal awareness of the public goods delivered by HNV farming is rising, and some policy support options have been developed (Lomba et al. 2020). However, a recent European EIP-AGRI expert report on HNV farming concluded that these efforts have so far not halted the decline in these systems and the loss of their associated biodiversity (European Commission 2016). Long-term monitoring data for globally threatened bird species in Mediterranean agroecosystems point to a similar trajectory (Palacín and Alonso 2018).

Dehesa and montado farms typically integrate extensive production of various combinations of cattle, sheep, goats, and pigs, with forest management and, in some cases, ancillary cropping. For simplicity they are all termed dehesas in this study. Major crops include grass and browse for livestock, acorns for swine feed, and cork. Other products may include game, firewood, wild plants, and mushrooms. Dehesas generally consist of privately owned farms of a few hundred hectares in size (Plieninger et al. 2004), although common and public forms of ownership exist. Central to the dehesa system are oak stands of different ages or in different management phases that are managed to be open enough to maintain the grass understory (Urbano 2010). Extending across 3.1 million hectares in the southwestern Iberian Peninsula (Moreno and Pulido 2009), dehesas form Europe's largest regional HNV farming system. The dehesa system is renowned for the complementarity of pastoral, agricultural, and forestry components. Characteristics of the system include high resource use efficiency, reliance on natural processes, and low dependency on external inputs (Rolo et al. 2016). Dehesas have also generated substantial interest because

\footnotetext{
${ }^{1}$ Department of Agricultural Economics and Rural Development, University of Göttingen, ${ }^{2}$ Faculty of Organic Agricultural Sciences, University of Kassel, ${ }^{3}$ Institute for Dehesa Research (INDEHESA), Forestry School, Plasencia, University of Extremadura, ${ }^{4}$ Department of Environmental Science, Policy, \& Management, University of California - Berkeley
} 
of the ecosystem services provided, including carbon storage, wildfire protection, aesthetic values, recreation, ecotourism, and sense of place (Garrido et al. 2017, Moreno et al. 2018).

Dehesa systems have become internationally known for supporting outstanding levels of biodiversity, a characteristic that qualified them for listing in the EU Habitats Directive as a natural habitat type of community-wide interest. Consequently, a large share of dehesas has been included in the EU Natura 2000 network of protected areas, attracting many visitors and leading to the development of diverse conservation measures (SánchezMartín et al. 2019). Up to 140 species of conservation concern that inhabit dehesas are listed in the Annexes of European Birds and Habitats Directives. These represent $9 \%-34 \%$ of the terrestrial vertebrates, $14 \%$ of the plants, and $69 \%$ of the mammals listed in the Directives for Spain (Díaz et al. 2013). Santos-Reis and Correia (1999) identified 264 fungi, 75 bryophytes, 304 vascular plant, and 121 vertebrate species in a single 220 ha montado. Moreno et al. (2016) recorded 504 plant, 140 bee, 161 spider, and 25 earthworm species in a 5000-ha area covered by dehesas. Overall, dehesas sustain higher species richness than neighboring oak forests for several taxonomic groups, especially for species-rich groups such as passerine birds, diurnal butterflies, and herbaceous plants (but less markedly for medium-sized and large mammals and woody plants; Díaz et al. 2013). Dehesas harbor several globally threatened species that depend on landscape diversity because they simultaneously exploit different habitat types (Carrete and Donázar 2005). Flagship species such as Imperial Eagles (Aquila adalberti), Black Vultures (Aegypius monachus), Black Storks (Ciconia nigra), Common Cranes (Grus grus), and Iberian lynx (Lynx pardina) use dehesas as feeding habitat, and adjacent forest and shrubland for breeding. Dehesas alone do not maintain a large proportion of critically endangered species. However, the coexistence of dehesas with other habitat types at the landscape scale contributes to the maintenance of a large proportion of the species of European conservation concern (Díaz et al. 2013).

The study of dehesas provides an opportunity to explore what global insights might be derived from regional-level, place-based research. The dehesa system is uniquely confined to the Iberian Peninsula, though similar agroforestry systems occur in France, Italy, and Greece (den Herder et al. 2017) as well as in Northern Africa and Western Asia (Moreno and Rolo 2019). Although dehesas have been sporadically described by foreign researchers for a long time (e.g., Smith 1916, Parsons 1962), international research on it started to develop systematically in the mid-1980s. According to the Web of Science, dehesas have been explicitly addressed in 679 international studies published between 1985 and 2020 and cited 9190 times as of 10 August 2020. For comparison, orchard meadows (another outstanding European agroforestry system of high nature value) have been the subject of only 20 studies listed in the Web of Science. The complexity of the dehesa system offers research questions for multiple disciplines, including forestry, agronomy, agroforestry, range management, forest ecology, conservation science, rural sociology, and environmental history. This complexity comes with the risk of knowledge being fragmented across individual studies and disciplines.
After 35 years of international publications on dehesas, we see an opportunity to take stock of the findings from research over time. Campos et al. (2013) have synthesized literature on the management of oak woodlands in Mediterranean-climate regions, comparing Spain and California; Moreno and Rolo (2019) compiled studies of the biophysical basis of dehesa functioning and dynamics; and Leal et al. (2019) reviewed the sustainability implications of cork oak woodlands in Western Europe and North Africa. However, a synthesis of the full body of literature on the links between land use and management practices, biodiversity, and policy in dehesas from a "high nature value farming system" perspective has not been conducted. The aim of this study is to synthesize international studies on conservation problems in dehesas and montados through a socialecological lens. For this purpose, we formulate the following research questions (Fig. 1):

- How has nature conservation been studied in the dehesa system?

- What are the indirect drivers and land management pressures influencing the ecological state of dehesas?

- What key landscape and land use features characterize the ecological reference state of dehesas?

- Which species groups and ecosystem services are affected by changes in the state of dehesas?

- What management and policy responses have been suggested or developed?

\section{METHODS}

We reviewed scientific studies that covered nature conservation issues in the dehesa system. Because we were primarily interested in international scholarly evidence, we searched for studies included in the Web of Science Core Collection database. In our search, we used the keywords "dehesa*" and "montado*" in titles, keywords, and abstracts. We covered literature published from 1985 (when the first study using the term "dehesa" was published) up to and including 2020. This yielded 679 studies. Selection of relevant studies was a three-stage process. We defined studies as relevant if they centered on dehesas or montados (composed of grazed open stands of Quercus suber and Quercus ilex) in Spain or Portugal (Fig. 2). Relevant studies had to focus on the links between biodiversity and land use and/or between land use and governance. For example, we excluded studies that focused on basic ecology (without conservation implications), soil fertility, hydrology, animal breeding, or food quality of dehesa products. We considered only empirical studies and excluded opinion, conceptual, and review papers.

We took a conservative approach and in cases of doubt passed studies on to the next phase. After a joint screening to calibrate assessment among co-authors, the selection was performed by the first author. In the first round, we selected 293 studies based on their titles. In the second round, we selected 154 studies based on their abstracts. We assessed the full papers in a third round and retained only studies that were deeply engaged with conservation and natural resource management issues. The remaining 128 papers are our study sample (cf. Appendix 1 for a full list of the sample). 
Fig. 1. Research questions organized within the Drivers - Pressures - State - Impacts Responses (DPSIR) framework.

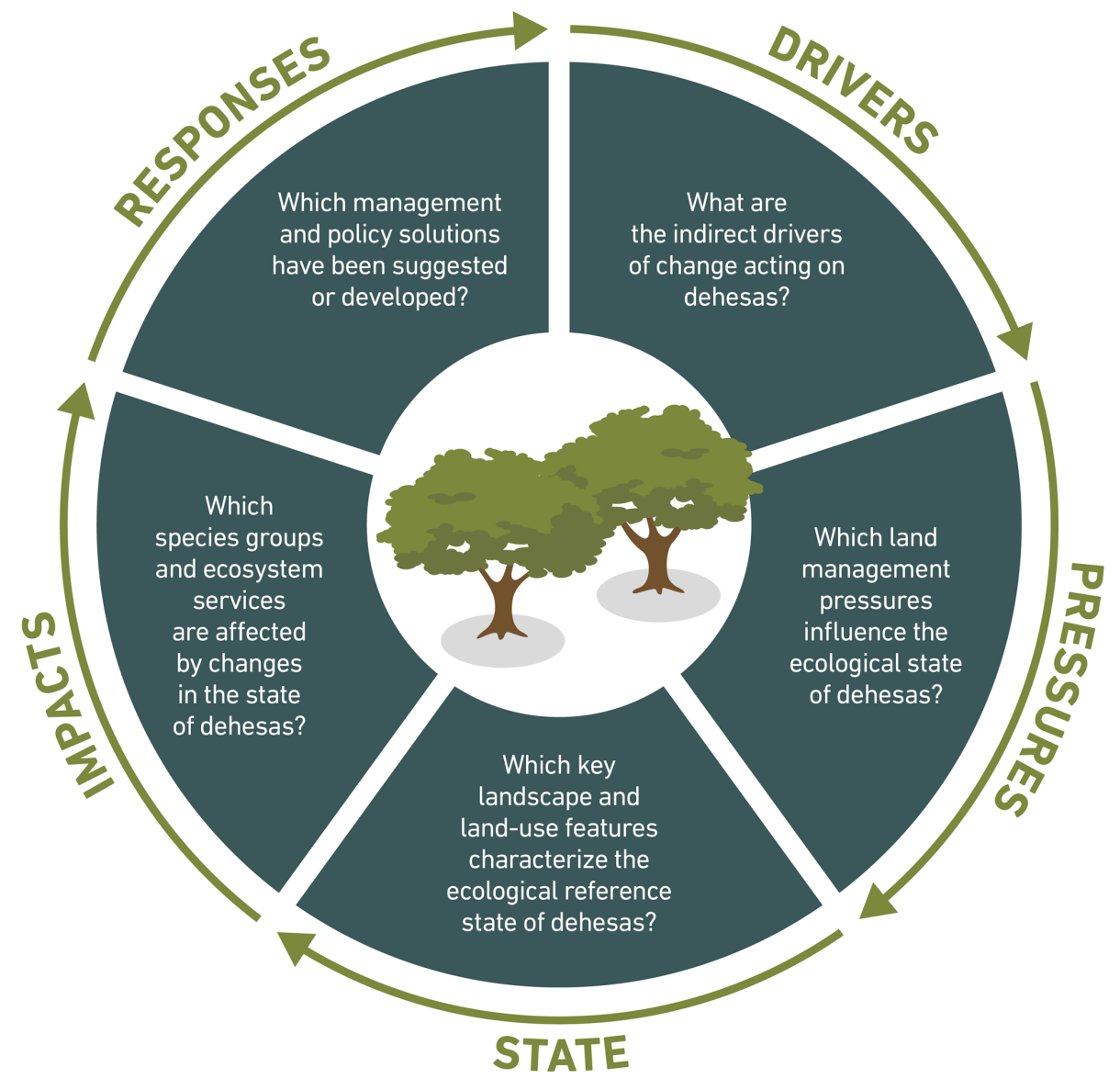

Fig. 2. Examples of holm oak (Quercus ilex, left) dominated dehesa and cork oak (Quercus suber, right) dominated montado.

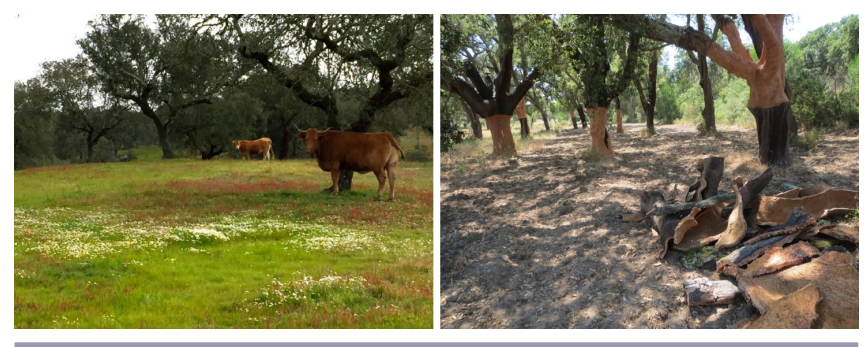

Similar to Hanspach et al. (2020), we combined qualitative and quantitative approaches to synthesize the diverse nature conservation literature on dehesas. We extracted nine categories (Table 1) for which we then calculated descriptive statistics. Our assessment of conservation trends in dehesas was structured into five categories according to the "Drivers - Pressures - State Impacts - Responses" (DPSIR) framework. DPSIR is a general framework developed by the European Environment Agency and has been frequently used for the integrated assessment of environmental resources (Stanners et al. 2007). We adapted the DPSIR framework to the dehesa context, drawing on similar contextualization exercises in the area of biodiversity research (Maxim et al. 2009). Whereas other work with the DPSIR framework has focused on analyzing specific and well-delimited issues, e.g., noise hazards (Rieder et al. 2015), we analyze dehesas as a complex system in which a multitude of drivers, pressures, states, impacts, and responses are interacting. For "drivers" we assessed broad underlying causes of change, drawing on the typology established by Costa et al. (2014). As "pressures" we included all direct causes of change, drawing on categories defined by van Vliet et al. (2015) and Plieninger et al. (2016), but adapting these to specific threats mentioned in the studies. For "state" we considered the landscape-level ecological state of dehesas described in the studies as archetypical, thereby defining the reference state (McNellie et al. 2020) for the DPSIR framework. For "impacts" we were interested in biodiversity trends (declines or increases in the richness, diversity, or abundance of species groups) and in changes in ecosystem service supply resulting from drivers and pressures. Under "responses" we assembled all potential or existing management and policy strategies mentioned positively in the studies. These were inductively coded in categories, including both management responses and policy 
responses. Besides formally coding the information from the studies into the categories mentioned in Table 2, we noted illustrative examples of drivers, pressures, states, impacts, and policy responses. We performed frequency analyses to characterize the studies according to the aforementioned categories.

Fig. 3. Number of scientific studies published on dehesas in general (light green, $n=679$ ) and specifically on nature conservation issues (dark green, $\mathrm{n}=128$ ).

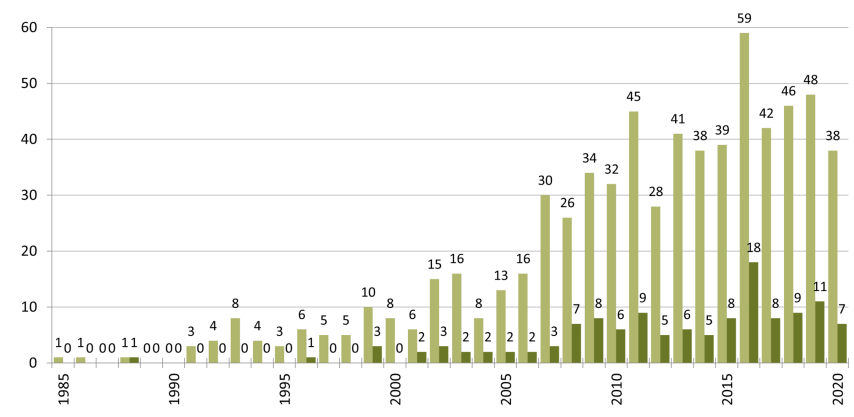

Fig. 4. Distribution of dehesas across the Iberian Peninsula (green) and number of studies conducted in each Spanish province / Portuguese district (sources: CORINE Land Cover, European Environment Agency, Eurostat).

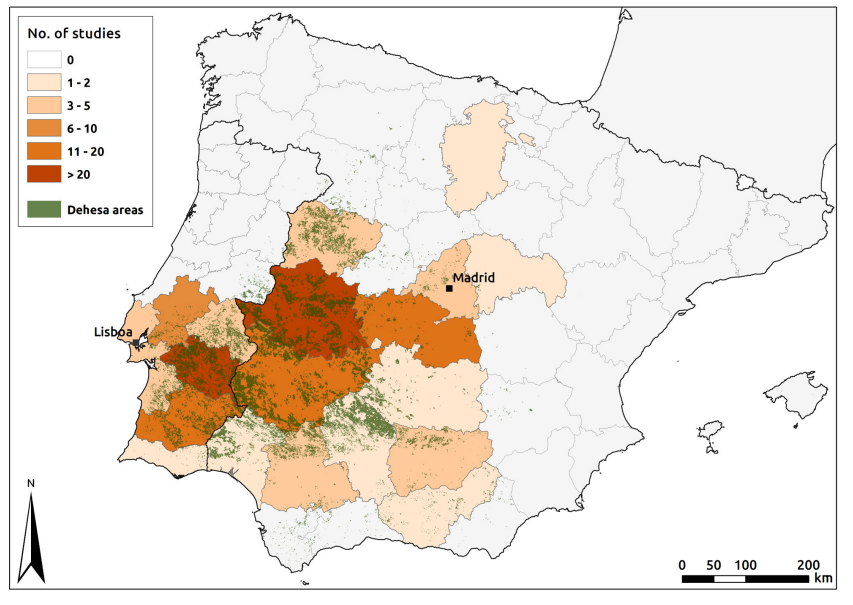

\section{RESULTS}

Study characteristics

We found a total of 128 international studies focusing on nature conservation in dehesas (Appendix 1). The first study included in our sample appeared in 1988, and was followed by a steady growth in publications on dehesas and nature conservation that leveled out around 2008 (Fig. 3). Dehesa studies are geographically balanced, with 65 studies conducted in Spain, 57 in Portugal, and six bi-national studies. All major regions where dehesas occur have been covered, including a total of 13 Spanish provinces and seven Portuguese districts (Fig. 4). Studies have been published in 56 journals altogether (Fig. 5).
Fig. 5. Percentage of studies following different analytical approaches.

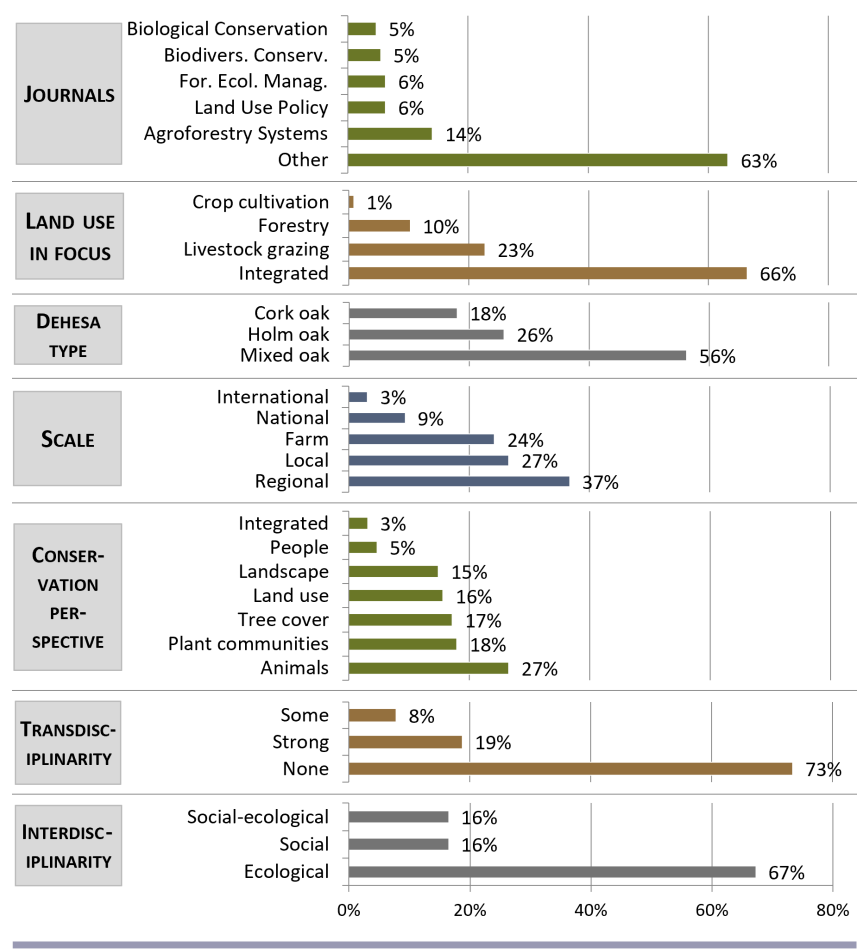

Table 1. Categories used for coding the study characteristics.

\begin{tabular}{|c|c|c|}
\hline Name & Description & Categories \\
\hline Year & Year of publication & E.g., 1999, 2000 \\
\hline Journal outlet & Journal name & $\begin{array}{l}\text { E.g., Ecology and } \\
\text { Society, Conservation } \\
\text { Biology }\end{array}$ \\
\hline Study area & $\begin{array}{l}\text { Approximate location of } \\
\text { the study (province/ } \\
\text { district level) }\end{array}$ & E.g., Evora, Cáceres \\
\hline Land use & $\begin{array}{l}\text { Management practices } \\
\text { in focus }\end{array}$ & $\begin{array}{l}\text { Forestry, Livestock } \\
\text { grazing, Crop } \\
\text { cultivation, Integrated }\end{array}$ \\
\hline Dehesa type & Dominant tree species & $\begin{array}{l}\text { Holm oak, Cork oak, } \\
\text { Mixed holm oak, and } \\
\text { cork oak }\end{array}$ \\
\hline Scale of analysis & $\begin{array}{l}\text { Spatial scale at which } \\
\text { the study was conducted }\end{array}$ & $\begin{array}{l}\text { National, Regional, } \\
\text { Local, Farm }\end{array}$ \\
\hline $\begin{array}{l}\text { Conservation } \\
\text { perspective }\end{array}$ & $\begin{array}{l}\text { Environmental resource } \\
\text { in focus }\end{array}$ & $\begin{array}{l}\text { Animals, Plant } \\
\text { communities, Tree cover, } \\
\text { Landscapes, People, } \\
\text { Land use, Integrated }\end{array}$ \\
\hline Transdisciplinarity & $\begin{array}{l}\text { Level of stakeholder } \\
\text { engagement }\end{array}$ & Strong, Some, None \\
\hline Interdisciplinarity & $\begin{array}{l}\text { Level of } \\
\text { interdisciplinary } \\
\text { integration }\end{array}$ & $\begin{array}{l}\text { Social only, Ecological } \\
\text { only, Integrated social- } \\
\text { ecological }\end{array}$ \\
\hline
\end{tabular}


Table 2. Categories used for coding drivers, pressures, state, impacts, and responses.

\begin{tabular}{|c|c|c|}
\hline Name & Description & Categories \\
\hline Drivers & $\begin{array}{l}\text { Indirect drivers of } \\
\text { change }\end{array}$ & $\begin{array}{l}\text { Natural, Political, Economic, } \\
\text { Technological, Sociocultural }\end{array}$ \\
\hline Pressures & $\begin{array}{l}\text { Direct pressures on } \\
\text { dehesa reference state as } \\
\text { a result of land } \\
\text { management actions }\end{array}$ & $\begin{array}{l}\text { Conversion to other land use, } \\
\text { Land abandonment, Tree age } \\
\text { structure, Changes in forest } \\
\text { management, Changes in crop } \\
\text { cultivation, Changes in livestock } \\
\text { grazing }\end{array}$ \\
\hline State & $\begin{array}{l}\text { Landscape-level } \\
\text { reference state, } \\
\text { expressed as typical or } \\
\text { ideal in the conservation } \\
\text { literature }\end{array}$ & $\begin{array}{l}\text { Extensive livestock grazing, } \\
\text { Scattered oak stands, } \\
\text { Unfragmented ecosystems, } \\
\text { Diverse land use / cover, Rich } \\
\text { landscape elements }\end{array}$ \\
\hline Impacts & $\begin{array}{l}\text { Consequences of drivers } \\
\text { and pressures on } \\
\text { richness / diversity / } \\
\text { abundance of particular } \\
\text { species groups or in } \\
\text { supply of ecosystem } \\
\text { services }\end{array}$ & $\begin{array}{l}\text { Birds, Mammals, Reptiles, } \\
\text { Amphibians, Invertebrates, } \\
\text { Plant communities, Provisioning } \\
\text { ecosystem services, Regulating } \\
\text { ecosystem services, Cultural } \\
\text { ecosystem services }\end{array}$ \\
\hline Responses & $\begin{array}{l}\text { Potential or existing } \\
\text { management or policy } \\
\text { strategies for } \\
\text { conservation }\end{array}$ & $\begin{array}{l}\text { Landscape management, Forest } \\
\text { management, Rangeland } \\
\text { management, Cropland } \\
\text { management, Business } \\
\text { management, Information / } \\
\text { knowledge, Regulation, } \\
\text { Economic incentives }\end{array}$ \\
\hline
\end{tabular}

Most studies approached dehesa farms as integrated agroforestry systems, while others focused on livestock grazing or forestry. All major types of oak stands were covered, with mixed holm oak and cork oak stands being most frequent. Different spatial scales were addressed in the study sample, covering farm, local, regional, and national levels. However, international studies investigating the full range of dehesas in Spain and Portugal were rare. The conservation focus of studies was most frequently animals and plant communities.

A large majority of studies did not include the perspectives of stakeholders. Those with some stakeholder involvement often used interviews or mail surveys at some stage. Studies reporting a more intensive stakeholder involvement used techniques like focus groups, Delphi assessment, or follow-up surveys. As to disciplinary approaches, most studies focused either on ecological or social issues. However, there were some interdisciplinary socialecological studies. These examined, for example, links between land management and ecosystem services, social-ecological drivers of land use change, or cost-effective conservation measures based on the integration of biodiversity and farm economics data.

\section{Drivers}

Economic drivers were mentioned most often and technological drivers less often (Fig. 6). Economic drivers often referred to the declining profitability of traditional dehesa products and pressures to intensify and simplify agricultural production. The larger context of the economic crisis in traditional agriculture starting in the 1960s, and the transition of Spain and Portugal to market economies in the 1970s, was also highlighted. Among other economic drivers were a focus on short-term cash flows, increasing labor costs, limited recognition and commercial promotion of the environmental values of dehesa products, and increasing competition for land. This was related to deficits in the organization of the producing sector, for instance in terms of value addition, value chain optimization, and producer cooperation. Natural drivers included multiple aspects of climate change, such as an increased frequency and severity of wildfires and an increasing frequency of droughts, in addition to several pests and diseases affecting important components of the dehesa system (sudden oak death, African swine fever, rabbit disease, invasive species). Socio-cultural drivers referred to processes of rural outmigration, rural change, and population aging, often leading to decreasing availability of labor on dehesa farms, generational renewal, or land abandonment. Larger societal modernization and urbanization processes were also addressed, together with low consumer awareness of biodiversity and ecosystem services from dehesas. On the other hand, new lifestyles and demand for dehesa contributions to human well-being, landscape aesthetics, hunting and leisure opportunities, and public discourse on ethical standards, heritage farming, or land stewardship are coming to the fore and were highlighted. The most prominent political drivers identified were the EU Common Agricultural Policy and other agricultural policies, noted as frequently incentivizing agricultural intensification and abandonment of multifunctional management practices. In particular, the direct payments within the first pillar of Common Agricultural Policy were recognized as an influential driver of intensification. Nature conservation policies that focus on restoring natural processes and discouraging livestock grazing were also highlighted as drivers, together with more specialized legislation on animal sanitary rules, e.g., interdicting disposal of livestock carcasses to vultures or the control of wild species that transmit diseases to livestock, such as red deer that transmit tuberculosis. Technological drivers comprised new farming practices such as the use of biocides, mineral fertilizers, and farm machinery.

Fig. 6. Drivers and pressures identified in the studies.

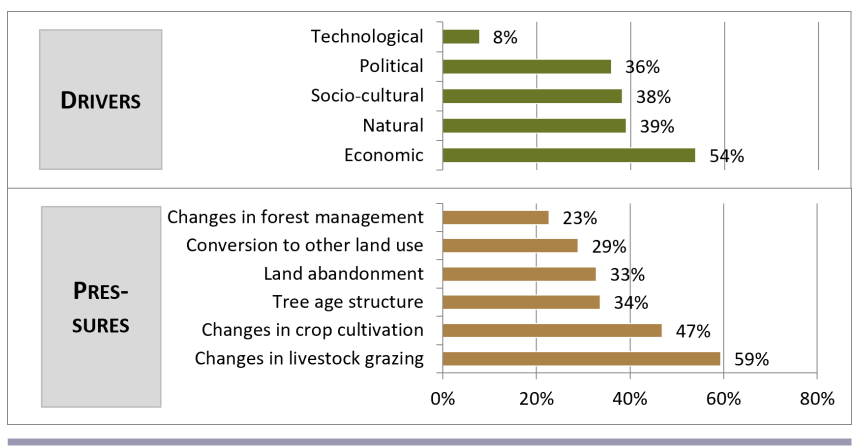

Pressures

Among the pressures directly affecting dehesas, changes in livestock management appeared most frequently (Fig. 6). Studies identified increases in livestock densities and multiple shifts: from sheep and goats to cattle, from the use of indigenous to introduced livestock breeds, from pastoral herding (e.g., transhumance) to 
year-round free-range grazing, from grazing natural rangelands to improved pastures (e.g., with sowed legumes), and from fodder self-sufficiency to a reliance on external fodder inputs. In some cases, decreasing livestock densities were reported as pressures. Changes in crop cultivation included a simplification of farming systems by abandoning rain-fed crop cultivation and intensifying the remaining uses. This was described as an overall trend from integral, holistic uses of land resources toward more monofunctional land management and less diversified, singlecommodity production. Tree age structure was another frequently mentioned category of pressure. It included observations of oak stands that are aging, in poor health, or at the end of their life span, but also concerns about tree recruitment failure, as observed through a lack of seedlings and saplings because of continuous grazing and/or climate change. Land abandonment meant the abandonment of all management activities without replacement, most typically followed by shrub encroachment. Conversion to other land uses referred to a fundamental transformation to a new land system. Land uses mentioned included irrigated arable crops, eucalypt and pine plantations (for producing pulp and paper), intensive hunting areas, afforestation with native tree species, olive groves, and more recently, almonds and other nut trees, urban areas, dams, and road infrastructure. Removal of oaks is frequently part of the conversion process. Changes in forest management, the least frequently cited category, comprised both increases (e.g., use of pesticides, vegetation clearing) and decreases (e.g., pruning, oak maintenance, use of acorns for pig fattening) in practices.

\section{Reference state}

Studies referenced their findings to an archetypical ecological state often described in fairly generic but remarkably consistent ways, defining together a generalized reference state (McNellie et al. 2020). Diverse land use / cover was the most frequently mentioned characteristic used for describing the reference state for dehesas (Fig. 7). The diverse and multifunctional land uses, e.g., multiple combinations of grazing, forest management, and ancillary crop cultivation plus other side-activities, and their variation over space and time were described as creating complex landscape patterns and high spatial (vertical and horizontal) heterogeneity. These patterns form mosaics of different vegetation structures including open and closed stands of shrubs or trees, varying levels of tree density, and patches of high and low grazing intensities. Combinations of oaks with different layers of pastures, shrublands, and cultivated lands create multiple ecotones, thus supporting diverse species assemblages. Overall, the semi-natural character of these landscape patterns and the constantly required human interventions were emphasized. The presence of scattered oak stands was another important defining feature, providing keystone structures and ecosystem engineering. These stands were described as typically extending across large areas and occurring in a scattered pattern on the landscape, with an open character of around $30 \%-50 \%$ canopy cover. The identification of extensive livestock grazing as an important characteristic was based on the fact that dehesas are shaped by Mediterranean pastoralism that relies on local resources and makes limited use of external inputs. Rich landscape elements comprised structures that provide habitats and increase spatial heterogeneity, for instance, dry stone walls, fruit orchards, small olive groves, ponds, and riparian areas. The unfragmented ecosystems category highlighted dehesas as large-scale habitat with low levels of disturbance.
Fig. 7. Characteristics of the reference state and the impacts of the drivers and pressures on biodiversity and ecosystem services identified in the studies.

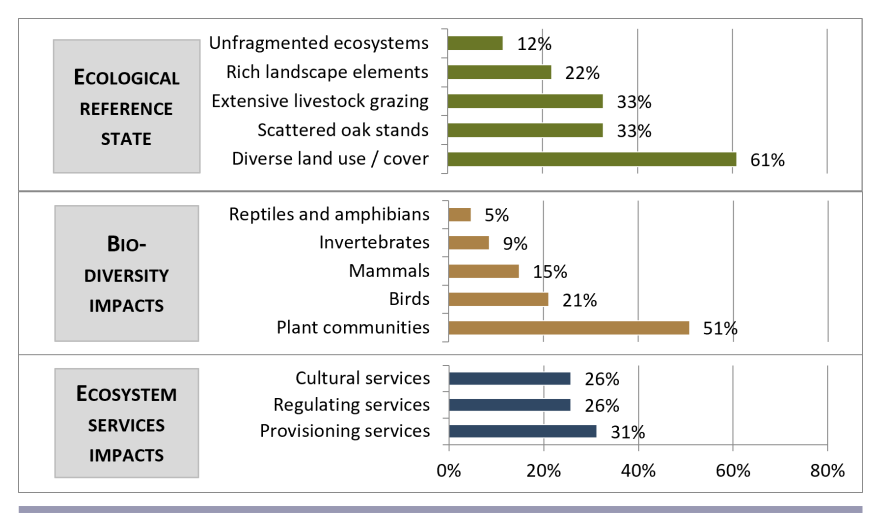

\section{Impacts on biodiversity and ecosystem services}

Multiple impacts on biodiversity were identified in the studies, covering plant communities, birds, mammals, invertebrates, reptiles, and amphibians (Fig. 7), but also epiphytic lichen or soil macrofauna and fungal communities. Pressures on broad species groups, e.g., butterflies or dung beetles, and on single species were investigated. Individual species of interest often were rare and/or charismatic birds, e.g., Common Crane, Imperial Eagle, Black Vulture, and mammals, or keystone species of importance for particular ecosystem functions or services, e.g., jay, wild rabbits, or wood mouse. Impacts on biodiversity included direct effects, such as the negative impact of soil tillage on soil macrofauna and fungal communities. Indirect and cascading effects of vegetation shifts on different taxa were also described, for example because of a change in the availability of resources (water, forage) refugia, and microclimates. Studies pointed to the complex, interconnected, and often counteracting relationships between land use activities and biodiversity and how outcomes were often dependent on environmental factors. The reported effect of grazing on the diversity of plant communities, for instance, varied among the papers, and was shown to be co-influenced by the availability of water and the presence of scattered trees. Although land abandonment and shrub encroachment were reported as increasing the risk of wildfire occurrence, maintaining a protective shrub layer was often reported to positively affect oak tree regeneration. Feedback loops were identified between slowly proceeding land use transitions and abrupt landscape changes catalyzed by wildfires. For example, decreased habitat patch size and connectivity caused by wildfires was shown to limit progression to late-successional plant communities and favor the persistence of fire-prone plant species.

Impacts on provisioning, regulating, and cultural ecosystem services also came up frequently. Among the provisioning services mentioned were mainly agricultural and forestry goods, such as high-quality food, meat and dairy products, fighting bulls, fodder, and cork, but also wild resources such as game, mushrooms, wild asparagus, or berries. Regulating ecosystem services, including control of wildfires and soil erosion, were frequently highlighted, as well as services such as climate regulation, control of water 
quality, and maintenance of hydrological cycles. Affected cultural services included aesthetic values, outdoor recreation and ecotourism, cultural heritage values, regional identity, and traditional ecological knowledge. Impacts on real estate values and on physical and mental health were also mentioned.

\section{Management and policy responses}

Suggested management responses focused on landscape, forest, rangeland, business, and cropland management (Fig. 8). Landscape management responses were systems-based, calling for diverse land uses, creating distinct habitat structures, and providing multiple ecosystem services and different resources to wildlife, e.g., food or shelter, at the landscape scale. Increasing connectivity, managing land for carnivores, and maintaining and restoring habitat diversity and particular landscape features, e.g., wetlands, stone walls, wood piles, were additional responses suggested. Forest management responses were largely directed to ensuring effective regeneration of oak stands, for instance by sowing seedlings, fostering protective shrubs, or using tree protectors. Maintaining old trees, leaving decaying trees with cavities in dehesas, and conserving marginal oak populations were additional suggestions. Rangeland management responses mainly concerned maintaining intermediate levels of soil and vegetation disturbance. Locally adapted and low to medium livestock grazing levels were recommended, as were rotational practices and areas where grazing would be excluded over medium to long terms. Mixed-species grazing, better paddock management, and similar practices were also suggested. Cutting of shrubs should include fostering protective shrubby patches while preventing shrub encroachment, according to some papers. Cropland management referred to recommendations for increasing cropping and fallow lands in dehesas to provide resources for wildlife, increase heterogeneity, and improve selfsufficiency in producing supplementary fodder. At the same time, avoidance of intensive cereal production and of mechanized plowing (in particular near trees and watercourses) was advised. Business responses were largely dedicated to diversifying production (e.g., by harvesting and commercializing edible fungi and wild asparagus or selling sclerophyllous shrub cuttings as biofuels) and to fostering cooperation between producers. The need for marketing that makes visible the societal values generated by dehesas, and that reaches new consumer groups, such as urban young people as well as socially and environmentally responsible consumers, was mentioned. Certification and labeling, e.g., geographic indication labels, Forest Stewardship Council, and branding to strengthen the link of these labels to distinct land management practices was emphasized.

Policy responses were distributed across economic incentives, regulation, and information/knowledge categories (Fig. 8). Suggested economic incentives focused strongly on the EU Common Agricultural Policy, its general maintenance, and specific advancements, e.g., better support for low-intensity farming and extensive grazing, oak planting and protection, or targeting of specific plant or bird assemblages of conservation interest. Furthermore, general transformations of the funding model were mentioned to support multifunctionality, heterogeneity, and sustainability of land use. This included suggestions to convert agricultural support into a payment scheme for multiple ecosystem services. Introducing tax breaks and schemes that are regionally specific, foster cooperation, and address the needs of private landowners were also highlighted. Regulation included the establishment of protected areas, e.g., biosphere reserves, and clearer legal definitions of "good practice" in dehesa management. Information/knowledge referred to training, information, and support activities for land managers through extension services, but also to better monitoring of dehesa management through remote sensing. Further, studies called for participatory approaches in natural resource management and planning, as well as for governance forms embracing "land stewardship." Increased citizen awareness of dehesas through environmental education, preserving traditional pastoral and farming cultures, and facilitating cooperation among dehesa managers and broader stakeholders were also mentioned.

Fig. 8. Land management (a) and policy (b) responses suggested to support the reference state of dehesas identified in the studies.

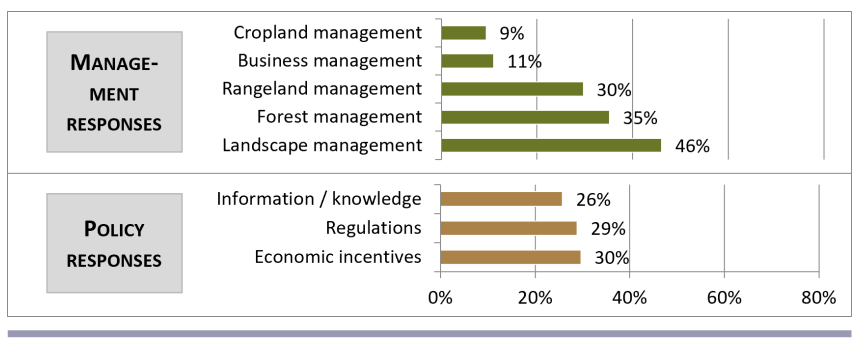

\section{DISCUSSION}

With this study we set out to explore how international research has investigated a land use system of high nature value, dehesas and montados. Although these are regional systems, mostly found on the Iberian Peninsula, they have generated enormous academic interest and have inspired research and activism for agroforestry, high nature value farming, and sustainable agriculture across Europe (Hartel et al. 2018, Moreno et al. 2018, Rolo et al. 2020). They may also offer inspiration for corresponding, but less investigated land use systems occurring at smaller scales, in particular in the southern and eastern part of the Mediterranean region. Dehesa research became established in the 1980s. Although the number of articles produced each year is not growing, we found a steady publication rate of 40-50 studies per year over the past 10 years. Geographically, the dehesa system has been investigated in all areas of Spain and Portugal where it occurs, with strong clustering in the provinces/regions of Alentejo (Portugal) and Extremadura (Spain). These regions are recognized as the dehesa "heartland," but are also home to the strongest research groups investigating the dehesas, based in Evora and Plasencia.

For effective management of social-ecological systems, it is recommended that they be assessed at multiple scales (Ostrom 2009). We found that the dehesa system has been examined at a multitude of spatial scales (from farm to national). However, the potential for analyses across whole countries that capitalize on recent advances in data availability, e.g., satellite data and PanEuropean databases such as LUCAS (d'Andrimont et al. 2020), and land-systems modeling has not yet been fully exploited for dehesas, which reflects the place-based character of international 
dehesa research. A frequently used synthesis approach that increased the generality of insights used cross-site comparisons across multiple local dehesa areas (Magliocca et al. 2015). Linking analyses from different scales can also help to recognize the different feedbacks and trade-offs for nature conservation that occur across the system (Díaz et al. 2015).

Overall, dehesa research has comprehensively addressed a broad range of topics and been published by multiple academic communities. Typically, individual components of the dehesa system have been investigated, e.g., tree regeneration or bird communities. Our review showed that the people owning, managing, using, or appreciating dehesas have been less frequently studied, and social science approaches have rarely been used. Furthermore, inter- and transdisciplinary approaches that integrate social and ecological sciences, take a systems perspective, and engage with stakeholders through different participatory schemes are relatively rare. Understanding local user values, rules, and knowledge systems can complement or even mitigate the undesirable effects of top-down governance approaches (Ostrom 2009) and avoid the decoupling of the social and ecological components of the system (Fischer et al. 2012). Increased understanding of the factors that motivate manager decisions and practices is important for dehesa conservation (Pinto-Correia et al. 2019). In addition to that, knowledge of the interactions of manager motives and multi-scaled and sometimes conflicting or overlapping policy attempts at incentivizing changes in behavior or maintaining traditional practices is essential. Given the changing state of dehesas, improved integration of social factors into dehesa research could strengthen understanding of the interrelationships of people and nature, the effects of policy interventions, and what is needed to ensure greater sustainability (Cortés Capano et al. 2019).

Although most studies investigated specific components of the land use system, when taken together and fit to the DPSIR framework, the studies we have reviewed allow for a full overview of the drivers, pressures, reference states, impacts, and responses relevant to dehesa systems. The drivers of the dehesa system are complex and interacting, as revealed in broader studies of land use change in Europe (van Vliet et al. 2015, Plieninger et al. 2016). A central driver identified is the repeatedly reformed EU Common Agricultural Policy (CAP) and its implications for dehesa economies. Dehesas are mostly private land, so the decisions and values of the landowner and the reactions of landowners to the CAP have a major influence on dehesa management (Fernandes and Guiomar 2016). On the one hand, the CAP is a basic support system fundamentally determining the current agricultural system in dehesas. The CAP also provides agri-environmental funding that allows dehesa farmers to improve marketing, introduce product labels, convert to organic agriculture, preserve indigenous livestock breeds, and/or maintain nature-friendly land uses (Pinto-Correia 2000). On the other hand, and more importantly, various stages in CAP reformation have created incentives for intensifying and simplifying the complex dehesa system (Pinto-Correia and Azeda 2017). For instance, the livestock-based payments applied in previous CAP periods (called coupled payments, still remaining partially maintained) provoked a steady increase of livestock densities to maximize subsidies and grant revenues (Gaspar et al. 2008). In addition, CAP rules have created direct barriers and other disadvantages for dehesa farms in qualifying for direct payments. For example, some eligibility rules have excluded dehesa parcels with a high tree density and/or the presence of a shrub layer, threatening the economic sustainability of the best conserved dehesa farms (Plieninger et al. 2015, Mosquera-Losada et al. 2018). A particular challenge for a multifunctional system such as dehesas is the prevailing organization of agricultural, forestry, and conservation policies into monofunctional sectors. Most other drivers mentioned in the reviewed studies are similar to those identified for high nature value farming systems in Europe, such as the generally low economic profitability of traditional land use, the challenge of rising wages in a labor-intensive system, or rural outmigration (Bieling et al. 2013, Plieninger and Bieling 2013, Lomba et al. 2020). Natural drivers, such as changing climate, pests, and diseases, also exacerbate many pressures on different system components, such as oaks and livestock.

Drivers translate into different pressures on dehesas (Fig. 1). Some pressures were reported to act specifically on livestock, forest, or crop components, while others affect the dehesa system as a whole. Interestingly, pressures from livestock production were often attributed to intensification processes, such as increases in stocking rates, shifts toward year-round grazing, introduction of high-performance breeds, de-emphasis on tree crops, and increased reliance on external resources. In contrast, pressures around forestry and crop cultivation were mainly expressed by extensification processes, such as ending oak pruning practices or abandoning cultivation. These pressures are mainly driven by CAP direct payments incentivizing simplified livestock raising through payments within the first pillar of the CAP (Guerra et al. 2016) and the higher profitability of livestock production compared to forestry production. As observed elsewhere (Schulp et al. 2019, Riechers et al. 2020), intensification and abandonment pressures act in the same area (potentially reinforcing each other) and lead to simplified forms of land use, in the case of dehesas creating a shift from a complex multifunctional agrosilvopastoral system to a simplified system focusing on livestock raising. Because both over-use and under-use are destructive to dehesa systems, managing them at intermediate disturbance levels can be challenging (Bugalho et al. 2011).

Understandings of the key characteristics that define the reference state of the dehesa for the purposes of the DPSIR framework come very close to conceptualizations of the desirable characteristics of HNV farming (Cooper et al. 2007, European Commission 2016). Most notably, a "mosaic" of land uses (grazing, forest management, rotational crops, other uses) and vegetation types (pasture, shrubland, fallow land, cultivated land, and tree stands in different densities) creates structural diversity at different spatial and temporal scales. In addition, livestock management practices are based on limited external inputs such as artificial fertilizers, biocides, and commercial feeds. Third, the presence of rich landscape elements, such as dry stone walls, dead trees, orchards, hedgerows, shrubby patches, ponds, watercourses, or old farm buildings (Moreno et al. 2016), adds to habitat diversity. And fourth, there is a large extent of unfragmented dehesas, which is of importance for disturbance-sensitive species.

Drivers, pressures, and ecological state shape the multiple impacts on plants, birds, and other aspects of biodiversity. Interestingly, dehesa research follows a trend observed for agroforestry and 
"trees outside forests" at large (e.g., Plieninger et al. 2012), in that assessment of various ecosystem services has moved into the foreground. Although the cultural values of land management have often been insufficiently taken up in the ecosystem services literature (Chan et al. 2012), cultural ecosystem services were studied on par with provisioning and regulating services in the research that we synthesized. This highlights the importance of dehesas for heritage values or as a repository of indigenous and local ecological knowledge. The fact that many dehesa ecosystem services can be classified into multiple categories, e.g., foraging of mushrooms or hunting as both provisioning and cultural ecosystem services, highlights how ecosystem services are coproduced by nature and people in this land-use system (Torralba et al. 2018). Our synthesis of existing literature from a DPSIR perspective can complement regional multi-scale ecosystem service assessments, which are increasingly promoted as a crucial step in tackling global biodiversity loss and environmental problems (e.g., Díaz et al. 2019).

Our examination of management responses revealed a plethora of available tools and models for nature-friendly dehesa management, ranging from specific, technical approaches, e.g., oak recruitment techniques, to system-based landscape management practices (Rolo et al. 2020). This pool of approaches could be analyzed with solution-scanning methods and made available as a practical toolbox (Hernández-Morcillo et al. 2018). The multitude of potential policy responses also indicates some parallels to the literature on integrated landscape management. Moving beyond single-topic policy solutions (for instance, a ban on fences that exclude wildlife or a prohibition on removing environmentally sensitive permanent grassland), territorial or landscape approaches to management, planning, and policy (Sayer et al. 2013) appear most useful for addressing the multiple drivers and pressures affecting dehesas and maintaining a desirable reference state (Varela et al. 2020). This requires in particular better coordination between sectorial activities and policies, most notably between agricultural and conservation policies (Therville et al. 2020). But although environmental policy integration has been a long-standing goal at EU level, multiple barriers and power imbalances, e.g., between farmers practicing diversified and simplified agriculture, make this integration difficult to achieve (Pe'er et al. 2019). An in-depth investigation of power relations and discourses around the dehesa system may improve understanding of which of these and other sectorial policies are stronger and why (Felipe-Lucia et al. 2015, BerbésBlázquez et al. 2016, Pinto-Correia et al. 2019). Implementing landscape approaches will also require higher levels of participation and self-organization and a broader integration of the different interests of the many actors with a stake in dehesas, which ideally would lead to a joint vision (Garrido et al. 2017). Although some of these actors may not be interested in nor have the capacity to design conservation-oriented measures, farmer participation and collaboration has been found essential for effective agri-environmental governance (Westerink et al. 2017). Participation has the potential to help mitigate some of the many conflicts and tensions around dehesas, but also to incorporate shared learning, monitoring, and evaluation in policy measures, thus creating cultural and social capital (Burton and Paragahawewa 2011). Reconfiguring CAP payments toward collaborative, regional-level action for biodiversity and toward a results-based payment scheme for ecosystem services may be the most comprehensive pathway toward dehesa stewardship. Many such models have been developed and tested in various parts of Europe and could be adapted to the dehesa context (Herzon et al. 2018, Moran et al. 2021).

\section{CONCLUSIONS}

This synthesis of the literature on dehesas and montados as "high nature value" farming systems illustrates how long-established Mediterranean land management practices have created a socialecological system with an extraordinary wealth of actors, practices, biodiversity, and ecosystem services, a system that has raised European and global conservation interest. Based on the synthesis of 128 published studies on nature conservation problems in the dehesa, we derive four key messages that address our research questions.

The first message is that dehesa research has informed high nature value farming internationally. However, much of the published research has treated the dehesa system in an unintegrated way, studying oak regeneration, pasture productivity, conservation of threatened species, or economic status as independent factors, when in fact they are highly interconnected and interdependent. Future dehesa studies would benefit from more integrative systems perspectives and from a stronger involvement of landowners and farmers in research processes.

Second, agricultural policies together with economic dynamics (as expressed in market prices) are key drivers. These drivers translate into pressures acting on dehesas, such as intensification of livestock raising, abandonment of forestry and crop cultivation, and land-use simplification. Policy measures directed to dehesas have often had a top-down character and single purpose focus. Most notably, the fate of the dehesa has been strongly influenced by the Common Agricultural Policy. The CAP has created complex and sometimes ill-suited rules for dehesas, targeting separate components, but not specifically the characteristics of the system: the parts but not the emergent whole. Currently prevailing policies, interacting with other drivers and pressures, appear to be leading to the decline of the socialecological values of the dehesa system.

Third, landscape features, most notably a mosaic of land uses, scattered tree cover, low-intensity livestock grazing, rich landscape structure, and unfragmented ecosystems, underpin the biodiversity and ecosystem services values of the dehesa system. Any conservation action should ensure maintenance and restoration of these essential components, and the interactions among components, in a high nature value farming system.

And finally, plenty of management and policy responses are available, but there is a need to move from single-topic to crosssectorial, landscape-level approaches. The dehesa system depends on measures and grants that fit the complexity of their biodiversity and ecosystem services values. Such policy responses should also take landowner and farmer perceptions, willingness, and capacity to innovate or to adopt measures for dehesa conservation into consideration. At the same time, the dehesa has become important for cultural identification and nature conservation, including the values and demands of a wider, more distant, and more urbanized society. 
Integrating the needs and goals of property owners and local communities with those of a distant public will be a continuing challenge for dehesa conservation. Accompanying this process by innovative governance models (in particular, by a CAP that acknowledges the multiple societal values provided by dehesas) is the beginning of what we hope will be a long story of successful conservation of this valuable and rich social-ecological system.

Responses to this article can be read online at: https://www.ecologyandsociety.org/issues/responses. $\mathrm{php} / 12647$

\section{Acknowledgments:}

We acknowledge support by the Open Access Publication Funds of the University of Göttingen. This research has been funded by the Deutsche Forschungsgemeinschaft (DFG, German Research Foundation), project number 426675955. It contributes to the Global Land Programme (https://www.glp.earthl) and the Programme on Ecosystem Change and Society (https:/lpecsscience.org/). We are grateful to Cristina Quintas-Soriano for assistance in the generation of the figures.

\section{Data Availability:}

The coded quantitative data are accessible on the Zenodo repository: https://doi.org/10.5281/zenodo. 4775861.

\section{LITERATURE CITED}

Berbés-Blázquez, M., J. A. González, and U. Pascual. 2016. Towards an ecosystem services approach that addresses social power relations. Current Opinion in Environmental Sustainability 19:134-143. https://doi.org/10.1016/j.cosust.2016.02.003

Bieling, C., T. Plieninger, and H. Schaich. 2013. Patterns and causes of land change: empirical results and conceptual considerations derived from a case study in the Swabian Alb, Germany. Land Use Policy 35:192-203. https://doi.org/10.1016/j. landusepol.2013.05.012

Bugalho, M. N., M. C. Caldeira, J. S. Pereira, J. Aronson, and J. G. Pausas. 2011. Mediterranean cork oak savannas require human use to sustain biodiversity and ecosystem services. Frontiers in Ecology and the Environment 9:278-286. https://doi. org/10.1890/100084

Burton, R. J. F., and U. H. Paragahawewa. 2011. Creating culturally sustainable agri-environmental schemes. Journal of Rural Studies 27:95-104. https://doi.org/10.1016/j.jrurstud.2010.11.001

Campos, P., L. Huntsinger, J. L. Oviedo, and P. F. Starrs. 2013. Mediterranean oak woodland working landscapes: dehesas of Spain and ranchlands of California. Springer, New York, New York, USA. https://doi.org/10.7818/ecos.2014.23-1.14

Carrete, M., and J. A. Donázar. 2005. Application of central-place foraging theory shows the importance of Mediterranean dehesas for the conservation of the cinereous vulture, Aegypius monachus.
Biological Conservation 126:582-590. https://doi.org/10.1016/j. biocon.2005.06.031

Chan, K. M. A., T. Satterfield, and J. Goldstein. 2012. Rethinking ecosystem services to better address and navigate cultural values. Ecological Economics 74:8-18. https://doi.org/10.1016/j. ecolecon.2011.11.011

Cooper, T., K. Arblaster, D. Baldock, M. Farmer, G. Beaufoy, G. Jones, X. Poux, D. McCracken, E. Bignal, B. Elbersen, D. Wascher, et al. 2007. Final report for the study on HNV indicators for evaluation. Contract notice 2006-G4-04. Institute for European Environmental Policy, London, UK.

Cortés Capano, G., T. Toivonen, A. Soutullo, and E. Di Minin. 2019. The emergence of private land conservation in scientific literature: a review. Biological Conservation 237:191-199. https:// doi.org/10.1016/j.biocon.2019.07.010

Costa, A., M. Madeira, and J. Lima Santos. 2014. Recent dynamics of evergreen oak wood-pastures in south-western Iberia. Pages 70-89 in T. Hartel, and T. Plieninger, editors. European wood-pastures in transition: a social-ecological approach. Routledge, London, UK. https://doi.org/10.4324/978$\underline{0203797082}$

d'Andrimont, R., M. Yordanov, L. Martinez-Sanchez, B. Eiselt, A. Palmieri, P. Dominici, J. Gallego, H. Reuter, C. Joebges, G. Lemoine, and M. van der Velde. 2020. Harmonised LUCAS insitu land cover and use database for field surveys from 2006 to 2018 in the European Union. Scientific Data 7:352. https://doi. org/10.1038/s41597-020-00675-Z

den Herder, M., G. Moreno, R. M. Mosquera-Losada, J. H. N. Palma, A. Sidiropoulou, J. J. Santiago Freijanes, J. Crous-Duran, J. A. Paulo, M. Tomé, A. Pantera, V. P. Papanastasis, K. Mantzanas, P. Pachana, A. Papadopoulos, T. Plieninger, and P. J. Burgess. 2017. Current extent and stratification of agroforestry in the European Union. Agriculture, Ecosystems \& Environment 241:121-132. https://doi.org/10.1016/j.agee.2017.03.005

Díaz, M., W. D. Tietje, and R. H. Barrett. 2013. Effects of management on biological diversity and endangered species. Pages 213-243 in P. Campos, L. Huntsinger, J. L. Oviedo, P. F. Starrs, M. Diaz, R. B Standiford, G. Montero, editors. Mediterranean oak woodland working landscapes: dehesas of Spain and ranchlands of California. Springer, New York, New York, USA. https://doi.org/10.1007/978-94-007-6707-2 8

Díaz, S., S. Demissew, J. Carabias, C. Joly, M. Lonsdale, N. Ash, A. Larigauderie, J. R. Adhikari, S. Arico, A. Báldi, et al. 2015. The IPBES Conceptual Framework - connecting nature and people. Current Opinion in Environmental Sustainability 14:1-16. https://doi.org/10.1016/j.cosust.2014.11.002

Díaz, S., J. Settele, E. S. Brondízio, H. T. Ngo, J. Agard, A. Arneth, P. Balvanera, K. A. Brauman, S. H. M. Butchart, K. M. A. Chan, et al. 2019. Pervasive human-driven decline of life on Earth points to the need for transformative change. Science 366:eaax3100. https://doi.org/10.1126/science.aax3100

European Commission. 2016. EIP-AGRI Focus group sustainable high nature value (HNV) farming. European Commission, Brussels, Belgium. [online] URL: https://ec.europa. eu/eip/agriculture/en/focus-groups/high-nature-value-hnv-farmingprofitability 
Felipe-Lucia, M. R., B. Martín-López, S. Lavorel, L. BerraqueroDíaz, J. Escalera-Reyes, and F. A. Comín. 2015. Ecosystem services flows: why stakeholders' power relationships matter. PLoS ONE 10:e0132232. https://doi.org/10.1371/journal. pone. 0132232

Fernandes, J. P., and N. Guiomar. 2016. Environmental ethics: driving factors beneath behavior, discourse and decision-making. Journal of Agricultural and Environmental Ethics 29:507-540. https://doi.org/10.1007/s10806-016-9607-x

Fischer, J., T. Hartel, and T. Kuemmerle. 2012. Conservation policy in traditional farming landscapes. Conservation Letters 5:167-175. https://doi.org/10.1111/j.1755-263X.2012.00227.x

Garrido, P., M. Elbakidze, P. Angelstam, T. Plieninger, F. Pulido, and G. Moreno. 2017. Stakeholder perspectives of wood-pasture ecosystem services: a case study from Iberian dehesas. Land Use Policy 60:324-333. https://doi.org/10.1016/j.landusepol.2016.10.022

Gaspar, P., M. Escribano, F. J. Mesías, A. Rodríguez de Ledesma, and F. Pulido. 2008. Sheep farms in the Spanish rangelands (dehesas): typologies according to livestock management and economic indicators. Small Ruminant Research 74:52-63. https:// doi.org/10.1016/j.smallrumres.2007.03.013

Guerra, C. A., M. J. Metzger, J. Maes, and T. Pinto-Correia. 2016. Policy impacts on regulating ecosystem services: looking at the implications of 60 years of landscape change on soil erosion prevention in a Mediterranean silvo-pastoral system. Landscape Ecology 31:271-290. https://doi.org/10.1007/s10980-015-0241-1

Hanspach, J., L. Jamila Haider, E. Oteros-Rozas, A. Stahl Olafsson, N. M. Gulsrud, C. M. Raymond, M. Torralba, B. Martín-López, C. Bieling, M. García-Martín, et al. 2020. Biocultural approaches to sustainability: a systematic review of the scientific literature. People and Nature 2:643-659. https://doi. org/10.1002/pan3.10120

Hartel, T., N. Fagerholm, M. Torralba, Á. Balázsi, and T. Plieninger. 2018. Social-ecological system archetypes for European rangelands. Rangeland Ecology \& Management 71:536-544. https://doi.org/10.1016/j.rama.2018.03.006

Hernández-Morcillo, M., P. Burgess, J. Mirck, A. Pantera, and T. Plieninger. 2018. Scanning agroforestry-based solutions for climate change mitigation and adaptation in Europe. Environmental Science \& Policy 80:44-52. https://doi. org/10.1016/j.envsci.2017.11.013

Herzon, I., T. Birge, B. Allen, A. Povellato, F. Vanni, K. Hart, G. Radley, G. Tucker, C. Keenleyside, R. Oppermann, E. Underwood, X. Poux, G. Beaufoy, and J. Pražan. 2018. Time to look for evidence: results-based approach to biodiversity conservation on farmland in Europe. Land Use Policy 71:347-354. https://doi.org/10.1016/j.landusepol.2017.12.011

Leal, A. I., R. A. Correia, J. M. Palmeirim, and M. N. Bugalho. 2019. Is research supporting sustainable management in a changing world? Insights from a Mediterranean silvopastoral system. Agroforestry Systems 93:355-368. https://doi.org/10.1007/ s10457-018-0231-9

Lomba, A., F. Moreira, S. Klimek, R. H. G. Jongman, C. Sullivan, J. Moran, X. Poux, J. P. Honrado, T. Pinto-Correia, T. Plieninger, and D. I. McCracken. 2020. Back to the future: rethinking socioecological systems underlying high nature value farmlands. Frontiers in Ecology and the Environment 18:36-42. https://doi. org/10.1002/fee.2116

Magliocca, N., T. Rudel, P. Verburg, W. McConnell, O. Mertz, K. Gerstner, A. Heinimann, and E. Ellis. 2015. Synthesis in land change science: methodological patterns, challenges, and guidelines. Regional Environmental Change 15:211-226. https:// doi.org/10.1007/s10113-014-0626-8

Maxim, L., J. H. Spangenberg, and M. O'Connor. 2009. An analysis of risks for biodiversity under the DPSIR framework. Ecological Economics 69:12-23. https://doi.org/10.1016/j. ecolecon.2009.03.017

McNellie, M. J., I. Oliver, J. Dorrough, S. Ferrier, G. Newell, and P. Gibbons. 2020. Reference state and benchmark concepts for better biodiversity conservation in contemporary ecosystems. Global Change Biology 26:6702-6714. https://doi.org/10.1111/ gcb. 15383

Moran, J., D. Byrne, J. Carlier, B. Dunford, J. A. Finn, D. Ó. hUallacháin, and C. A. Sullivan. 2021. Management of high nature value farmland in the Republic of Ireland: 25 years evolving toward locally adapted results-orientated solutions and payments. Ecology and Society 26(1):20. https://doi.org/10.5751/ ES-12180-260120

Moreno, G., S. Aviron, S. Berg, J. Crous-Duran, A. Franca, S. García de Jalón, T. Hartel, J. Mirck, A. Pantera, J. H. N. Palma, J. A. Paulo, G. A. Re, F. Sanna, C. Thenail, A. Varga, V. Viaud, and P. J. Burgess. 2018. Agroforestry systems of high nature and cultural value in Europe: provision of commercial goods and other ecosystem services. Agroforestry Systems 92:877-891. https://doi.org/10.1007/s10457-017-0126-1

Moreno, G., G. Gonzalez-Bornay, F. Pulido, M. L. Lopez-Diaz, M. Bertomeu, E. Juárez, and M. Diaz. 2016. Exploring the causes of high biodiversity of Iberian dehesas: the importance of wood pastures and marginal habitats. Agroforestry Systems 90:87-105. https://doi.org/10.1007/s10457-015-9817-7

Moreno, G., and F. Pulido. 2009. The functioning, management and persistence of dehesas. Pages 127-160 in A. RigueiroRodríguez, J. McAdam, and M. R. Mosquera-Losada, editors. Agroforestry in Europe. Springer, Dordrecht, The Netherlands. https://doi.org/10.1007/978-1-4020-8272-6 7

Moreno, G., and V. Rolo. 2019. Agroforestry practices: silvopastoralism. Pages 1-47 in M. R. Mosquera-Losada, and R. Prabh, editors. Agroforestry for sustainable agriculture. Burleigh Dodds Science, Cambridge, UK.

Mosquera-Losada, M. R., J. J. Santiago-Freijanes, A. Pisanelli, M. Rois-Díaz, J. Smith, M. den Herder, G. Moreno, N. FerreiroDomínguez, N. Malignier, N. Lamersdorf, et al. 2018. Agroforestry in the European common agricultural policy. Agroforestry Systems 92:1117-1127. https://doi.org/10.1007/ $\underline{\mathrm{s} 10457-018-0251-5}$

Ostrom, E. 2009. A general framework for analyzing sustainability of social-ecological systems. Science 325:419-422. https://doi.org/10.1126/science.1172133 
Palacín, C., and J. C. Alonso. 2018. Failure of EU biodiversity strategy in Mediterranean farmland protected areas. Journal for Nature Conservation 42:62-66. https://doi.org/10.1016/j.jnc.2018.02.008

Parsons, J. J. 1962. The acorn-hog economy of the oak woodlands of southwestern Spain. Geographical Review 52:211-235. https:// doi.org/10.2307/212957

Pe'er, G., Y. Zinngrebe, F. Moreira, C. Sirami, S. Schindler, R. Müller, V. Bontzorlos, D. Clough, P. Bezák, A. Bonn, B. Hansjürgens, A. Lomba, S. Möckel, G. Passoni, C. Schleyer, J. Schmidt, and S. Lakner. 2019. A greener path for the EU Common Agricultural Policy. Science 365:449-451. https://doi.org/10.1126/ $\underline{\text { science.aax } 3146}$

Pinto-Correia, T. 2000. Future development in Portuguese rural areas: how to manage agricultural support for landscape conservation? Landscape and Urban Planning 50:95-106. https:// doi.org/10.1016/s0169-2046(00)00082-7

Pinto-Correia, T., and C. Azeda. 2017. Public policies creating tensions in Montado management models: insights from farmers' representations. Land Use Policy 64:76-82. https://doi. org/10.1016/j.landusepol.2017.02.029

Pinto-Correia, T., N. Guiomar, M. I. Ferraz-de-Oliveira, E. SalesBaptista, J. Rabaça, C. Godinho, N. Ribeiro, P. Sá Sousa, P. Santos, C. Santos-Silva, et al. 2018. Progress in identifying high nature value montados: impacts of grazing on hardwood rangeland biodiversity. Rangeland Ecology \& Management 71:612-625. https://doi.org/10.1016/i.rama.2018.01.004

Pinto-Correia, T., J. Muñoz-Rojas, M. H. Thorsøe, and E. B. Noe. 2019. Governance discourses reflecting tensions in a multifunctional land use system in decay. Tradition versus modernity in the Portuguese montado. Sustainability 11:3363 https://doi.org/10.3390/su11123363

Plieninger, T., and C. Bieling. 2013. Resilience-based perspectives to guiding high nature value farmland through socioeconomic change. Ecology and Society 18(4):20. https://doi.org/10.5751/ es-05877-180420

Plieninger, T., H. Draux, N. Fagerholm, C. Bieling, M. Bürgi, T. Kizos, T. Kuemmerle, J. Primdahl, and P. H. Verburg. 2016. The driving forces of landscape change in Europe: a systematic review of the evidence. Land Use Policy 57:204-214. https://doi. org/10.1016/j.landusepol.2016.04.040

Plieninger, T., T. Hartel, B. Martín-López, G. Beaufoy, E. Bergmeier, K. Kirby, M. J. Montero, G. Moreno, E. Oteros-Rozas, and J. Van Uytvanck. 2015. Wood-pastures of Europe: geographic coverage, social-ecological values, conservation management, and policy implications. Biological Conservation 190:70-79. https://doi.org/10.1016/j.biocon.2015.05.014

Plieninger, T., J. Modolell y Mainou, and W. Konold. 2004. Land manager attitudes toward management, regeneration, and conservation of Spanish holm oak savannas (dehesas). Landscape and Urban Planning 66:185-198. https://doi.org/10.1016/ S0169-2046(03)00100-2

Plieninger, T., C. Schleyer, M. Mantel, and P. Hostert. 2012. Is there a forest transition outside forests? Trajectories of farm trees and effects on ecosystem services in an agricultural landscape in
Eastern Germany. Land Use Policy 29:233-243. https://doi. org/10.1016/j.landusepol.2011.06.011

Raatikainen, K. J., and E. S. Barron. 2017. Current agrienvironmental policies dismiss varied perceptions and discourses on management of traditional rural biotopes. Land Use Policy 69:564-576. https://doi.org/10.1016/j.landusepol.2017.10.004

Riechers, M., Á. Balázsi, L. Betz, T. S. Jiren, and J. Fischer. 2020. The erosion of relational values resulting from landscape simplification. Landscape Ecology 35:2601-2612. https://doi. org/10.1007/s10980-020-01012-W

Rieder, S., J. Hauenstein, U. Haefeli, and F. Landis 2015. Wirkungsanalyse Lärmbekämpfung. Bundesamt für Umwelt (BAFU), Bern, Switzerland.

Rolo, V., T. Hartel, S. Aviron, S. Berg, J. Crous-Duran, A. Franca, J. Mirck, J. H. Nunes Palma, A. Pantera, J. Amaral, et al. 2020. Challenges and innovations for improving the sustainability of European agroforestry systems of high nature and cultural value: stakeholder perspectives. Sustainability Science 15:1301-1315. https://doi.org/10.1007/s11625-020-00826-6

Rolo, V., D. Rivest, M. Lorente, J. Kattge, and G. Moreno. 2016. Taxonomic and functional diversity in Mediterranean pastures: insights on the biodiversity-productivity trade-off. Journal of Applied Ecology 53:1575-1584. https://doi.org/10.1111/1365-2664.12685

Sánchez-Martín, J.-M., R. Blas-Morato, and J.-I. RengifoGallego. 2019. The dehesas of Extremadura, Spain: a potential for socio-economic development based on agritourism activities. Forests 10:620. https://doi.org/10.3390/f10080620

Santos-Reis, M., and A. I. Correia 1999. Caracterizaçao da flora e fauna do montado da Heredade da Ribeira Abaixo (Grândola, Baixo Alentejo). CBA, Lisbon, Portugal.

Sayer, J., T. Sunderland, J. Ghazoul, J.-L. Pfund, D. Sheil, E. Meijaard, M. Venter, A. K. Boedhihartono, M. Day, C. Garcia, C. van Oosten, and L. E. Buck. 2013. Ten principles for a landscape approach to reconciling agriculture, conservation, and other competing land uses. Proceedings of the National Academy of Sciences of the United States of America 110:8349-8356. https://doi.org/10.1073/pnas.1210595110

Schulp, C. J. E., C. Levers, T. Kuemmerle, K. F. Tieskens, and P. H. Verburg. 2019. Mapping and modelling past and future land use change in Europe's cultural landscapes. Land Use Policy 80:332-344. https://doi.org/10.1016/j.landusepol.2018.04.030

Smith, J. R. 1916. The oak tree and man's environment. Geographical Review 1:3-19. https://doi.org/10.2307/207877

Stanners, D., P. Bosch, A. Dom, P. Gabrielsen, D. Gee, J. Martin, L. Rickard, and J.-L. Weber. 2007. Frameworks for environmental assessment and indicators at the EEA. Pages 127-144 in T. Hak, B. Moldan, and A. L. Dahl, editors. Sustainability indicators: a scientific assessment. Island, Washington, D.C., USA.

Strohbach, M. W., M. L. Kohler, J. Dauber, and S. Klimek. 2015. High nature value farming: from indication to conservation. Ecological Indicators 57:557-563. https://doi.org/10.1016/j. ecolind.2015.05.021 
Therville, C., M. Antona, and H. de Foresta. 2020. The policyscape of agroforestry within Mediterranean protected landscapes in France. Sustainability Science 15:1435-1448. https://doi.org/10.1007/s11625-020-00821-X

Torralba, M., E. Oteros-Rozas, G. Moreno, and T. Plieninger. 2018. Exploring the role of management in the coproduction of ecosystem services from Spanish wooded rangelands. Rangeland Ecology \& Management 71:549-559. https://doi.org/10.1016/j. rama.2017.09.001

Urbano, F. P. 2010. The dehesa/montado landscape. Pages 149-151 in C. Bélair, K. Ichikawa, B. Y. L. Wong, and K. J. Mulongoy, editors. Sustainable use of biological diversity in socio-ecological production landscapes. Technical Series no. 52. Secretariat of the Convention on Biological Diversity, Montréal, Québec, Canada.

van Vliet, J., H. L. F. de Groot, P. Rietveld, and P. H. Verburg. 2015. Manifestations and underlying drivers of agricultural land use change in Europe. Landscape and Urban Planning 133:24-36. https://doi.org/10.1016/j.landurbplan.2014.09.001

Varela, E., F. Pulido, G. Moreno, and M. Á. Zavala. 2020. Targeted policy proposals for managing spontaneous forest expansion in the Mediterranean. Journal of Applied Ecology 57:2373-2380. https://doi.org/10.1111/1365-2664.13779

Westerink, J., R. Jongeneel, N. Polman, K. Prager, J. Franks, P. Dupraz, and E. Mettepenningen. 2017. Collaborative governance arrangements to deliver spatially coordinated agri-environmental management. Land Use Policy 69:176-192 https://doi. org/10.1016/j.landusepol.2017.09.002

Wossink, A., and S. M. Swinton. 2007. Jointness in production and farmers' willingness to supply non-marketed ecosystem services. Ecological Economics 64:297-304. https://doi. org/10.1016/j.ecolecon.2007.07.003 


\section{Appendix 1. Primary Studies Selected in the Synthesis}

1. Acha A., and H. S. Newing. 2015. Cork oak landscapes, promised or compromised Lands? Human Ecology 43:601-611.

2. Allen H., W. Simonson, E. Parham, E. d. B. e. Santos, and P. Hotham. 2018. Satellite remote sensing of land cover change in a mixed agro-silvo-pastoral landscape in the Alentejo, Portugal. International Journal of Remote Sensing 39:4663-4683.

3. Almeida M., C. Azeda, N. Guiomar, and T. Pinto-Correia. 2016a. The effects of grazing management in montado fragmentation and heterogeneity. Agroforestry Systems 90:6985.

4. Almeida M., C. Guerra, and T. Pinto-Correia. 2013. Unfolding relations between land cover and farm management. Geografisk Tidsskrift-Danish Journal of Geography 113:97-108.

5. Almeida M., I. Loupa-Ramos, H. Menezes, S. Carvalho-Ribeiro, N. Guiomar, and T. Pinto-Correia. 2016b. Urban population looking for rural landscapes. Land Use Policy 53:44-55.

6. Aragón G., R. López, and I. Martínez. 2010. Effects of Mediterranean dehesa management on epiphytic lichens. The Science of the total environment 409:116-122.

7. Arosa M. L., R. Bastos, J. A. Cabral, H. Freitas, S. R. Costa, and M. Santos. 2017. Long-term sustainability of cork oak agro-forests in the Iberian Peninsula. Ecological Modelling 343:68-79.

8. Arosa M. L., R. S. Ceia, S. R. Costa, and H. Freitas. 2015. Factors affecting cork oak ( Quercus suber ) regeneration. Plant Ecology \& Diversity 8:519-528.

9. Arrondo E., M. Moleón, A. Cortés-Avizanda, J. Jiménez, P. Beja, J. A. Sánchez-Zapata, and J. A. Donázar. 2018. Invisible barriers. Biological Conservation 219:46-52.

10. Ascensão F., A. P. Clevenger, C. Grilo, J. Filipe, and M. Santos-Reis. 2012. Highway verges as habitat providers for small mammals in agrosilvopastoral environments. Biodiversity and Conservation 21:3681-3697.

11. Avilés J. M. 2004. Common cranes Grus grus and habitat management in holm oak dehesas of Spain. Biodiversity and Conservation 13:2015-2025.

12. Avilés J. M. 2019. Pruning promotes the formation of an insufficient number of cavities for hollow-dependent birds in Iberian Holm-oak dehesas. Forest Ecology and Management 453:117627.

13. Avilés J. M., F. J. Medina, J. M. Sánchez, and D. Parejo. 2002. Does temporal variability of winter common cranes in the dehesas depend on farming practices? Waterbirds 25:86-92.

14. Azul A. M., S. M. Mendes, J. P. Sousa, and H. Freitas. 2011. Fungal fruitbodies and soil macrofauna as indicators of land use practices on soil biodiversity in Montado. Agroforestry Systems 82:121-138.

15. Azul A. M., J. P. Sousa, R. Agerer, M. P. Martín, and H. Freitas. 2010. Land use practices and ectomycorrhizal fungal communities from oak woodlands dominated by Quercus suber L. considering drought scenarios. Mycorrhiza 20:73-88.

16. BalbontÍN J., J. J. Negro, J. H. Sarasola, J. J. Ferrero, and D. Rivera. 2008. Land-use changes may explain the recent range expansion of the Black-shouldered Kite Elanus caeruleus in southern Europe. Ibis 150:707-716. 
17. Bugalho M. N., F. S. Dias, B. Briñas, and J. O. Cerdeira. 2016. Using the high conservation value forest concept and Pareto optimization to identify areas maximizing biodiversity and ecosystem services in cork oak landscapes. Agroforestry Systems 90:35-44.

18. Bugalho M. N., X. Lecomte, M. Gonçalves, M. C. Caldeira, and M. Branco. 2011. Establishing grazing and grazing-excluded patches increases plant and invertebrate diversity in a Mediterranean oak woodland. Forest Ecology and Management 261:21332139.

19. Campos P., P. Ovando, and G. Montero. 2008. Does private income support sustainable agroforestry in Spanish dehesa? Land Use Policy 25:510-522.

20. Canteiro C., C. Pinto-Cruz, M. P. Simões, and L. Gazarini. 2011. Conservation of Mediterranean oak woodlands. Agroforestry Systems 82:161-171.

21. Carmona C. P., F. M. Azcárate, F. Bello, H. S. Ollero, J. Lepš, B. Peco, and M. Cadotte. 2012. Taxonomical and functional diversity turnover in Mediterranean grasslands. Journal of Applied Ecology 49:1084-1093.

22. Carmona C. P., F. M. Azcárate, E. Oteros-Rozas, J. A. González, and B. Peco. 2013. Assessing the effects of seasonal grazing on holm oak regeneration. Biological Conservation 159:240-247.

23. Carrete M., and J. A. Donázar. 2005. Application of central-place foraging theory shows the importance of Mediterranean dehesas for the conservation of the cinereous vulture, Aegypius monachus. Biological Conservation 126:582-590.

24. Castro H., V. Lehsten, S. Lavorel, and H. Freitas. 2010. Functional response traits in relation to land use change in the Montado. Agriculture, Ecosystems \& Environment 137:183-191.

25. Costa A., M. Madeira, J. Lima Santos, and Â. Oliveira. 2011. Change and dynamics in Mediterranean evergreen oak woodlands landscapes of Southwestern Iberian Peninsula. Landscape and Urban Planning 102:164-176.

26. Costa A., H. Pereira, and M. Madeira. 2009. Landscape dynamics in endangered cork oak woodlands in Southwestern Portugal (1958-2005). Agroforestry Systems 77:83-96.

27. Costa P., D. Medinas, B. M. Silva, A. Mira, N. Guiomar, E. Sales-Baptista, M. I. Ferraz-de-Oliveira, M. P. Simões, A. D. F. Belo, and J. M. Herrera. 2019. Cattle-driven forest disturbances impact ensemble composition and activity levels of insectivorous bats in Mediterranean wood pastures. Agroforestry Systems 93:1687-1699.

28. Curveira-Santos G., T. A. Marques, M. Björklund, and M. Santos-Reis. 2017. Mediterranean mesocarnivores in spatially structured managed landscapes. Agriculture, Ecosystems \& Environment 237:280-289.

29. da Silva P. M., C. A. S. Aguiar, I. Faria e Silva, and A. R. M. Serrano. 2011. Orchard and riparian habitats enhance ground dwelling beetle diversity in Mediterranean agroforestry systems. Biodiversity and Conservation 20:861-872.

30. da Silva P. M., C. A. S. Aguiar, J. Niemelä, J. P. Sousa, and A. R. M. Serrano. 2009. Cork-oak woodlands as key-habitats for biodiversity conservation in Mediterranean landscapes. Biodiversity and Conservation 18:605-619.

31. Díaz M., E. González, R. Muñoz-Pulido, and M. A. Naveso. 1996. Habitat selection patterns of common cranes Grus grus wintering in holm oak Quercus ilex dehesas of central Spain. Biological Conservation 75:119-123. 
32. do Rosário I. T., R. Rebelo, U. Caser, L. Vasconcelos, and M. Santos-Reis. 2019. Valuation of ecosystem services by stakeholders operating at different levels. Regional Environmental Change 19:2173-2185.

33. Escribano A. J., P. Gaspar, F. J. Mesías, and M. Escribano. 2016. The role of the level of intensification, productive orientation and self-reliance in extensive beef cattle farms. Livestock Science 193:8-19.

34. Escribano M., P. Gaspar, and F. J. Mesias. 2020. Creating market opportunities in rural areas through the development of a brand that conveys sustainable and environmental values. Journal of Rural Studies 75:206-215.

35. Esgalhado C., H. Guimarães, M. Debolini, N. Guiomar, S. Lardon, and I. Ferraz de Oliveira. 2020. A holistic approach to land system dynamics - The Monfurado case in Alentejo, Portugal. Land Use Policy 95:104607.

36. Fernandes J., F. Petrucci-Fonseca, M. Santos-Reis, and L. M. Rosalino. 2019. Drivers of Psammodromus algirus abundance in a Mediterranean agroforestry landscape. Agroforestry Systems 93:2281-2291.

37. Fragoso R., M. Santos-Reis, and L. M. Rosalino. 2020. Drivers of wood mouse body condition in Mediterranean agroforestry landscapes. European Journal of Wildlife Research 66:449.

38. Franco J. A., P. Gaspar, and F. J. Mesias. 2012. Economic analysis of scenarios for the sustainability of extensive livestock farming in Spain under the CAP. Ecological Economics 74:120-129.

39. Freitas M. d. B. C., M. R. Ventura-Lucas, L. Izquierdo, and C. Deblitz. 2020. The montado/dehesa cow-calf production systems in Portugal and Spain. Land 9:148.

40. Galantinho A., and A. Mira. 2009. The influence of human, livestock, and ecological features on the occurrence of genet (Genetta genetta). Ecological Research 24:671-685.

41. Gallego-Fernández J. B., M. R. García-Mora, and F. García-Novo. 1999. Small wetlands lost. Environmental Conservation 26:190-199.

42. Gálvez Bravo L., J. Belliure, and S. Rebollo. 2009. European rabbits as ecosystem engineers. Biodiversity and Conservation 18:869-885.

43. García del Barrio J. M., R. Alonso Ponce, R. Benavides, and S. Roig. 2014. Species richness of vascular plants along the climatic range of the Spanish dehesas at two spatial scales. Forest Systems 23:111.

44. Garrido P., M. Elbakidze, P. Angelstam, T. Plieninger, F. Pulido, and G. Moreno. 2017. Stakeholder perspectives of wood-pasture ecosystem services. Land Use Policy 60:324333.

45. Gaspar P., M. Escribano, and F. J. Mesias. 2016. A qualitative approach to study social perceptions and public policies in dehesa agroforestry systems. Land Use Policy 58:427-436.

46. Gaspar P., F. J. Mesías, M. Escribano, and F. Pulido. 2009. Sustainability in Spanish extensive farms (dehesas). Rangeland Ecology \& Management 62:153-162.

47. Gaspar P., F. J. Mesías, M. Escribano, A. Rodriguez de Ledesma, and F. Pulido. 2007. Economic and management characterization of dehesa farms. Agroforestry Systems 71:151-162.

48. Godinho C., and J. E. Rabaça. 2011. Birds like it corky. Agroforestry Systems 82:183195. 
49. Godinho S., N. Guiomar, R. Machado, P. Santos, P. Sá-Sousa, J. P. Fernandes, N. Neves, and T. Pinto-Correia. 2016. Assessment of environment, land management, and spatial variables on recent changes in montado land cover in southern Portugal. Agroforestry Systems 90:177-192.

50. Godinho S., A. P. Santos, and P. Sá-Sousa. 2011. Montado management effects on the abundance and conservation of reptiles in Alentejo, Southern Portugal. Agroforestry Systems 82:197-207.

51. Gómez-Limón J., and J. V. d. L. o. Fernández. 1999. Changes in use and landscape preferences on the agricultural-livestock landscapes of the central Iberian Peninsula (Madrid, Spain). Landscape and Urban Planning 44:165-175.

52. Gonçalves P., S. Alcobia, L. Simões, and M. Santos-Reis. 2012. Effects of management options on mammal richness in a Mediterranean agro-silvo-pastoral system. Agroforestry Systems 85:383-395.

53. Guiomar N., S. Godinho, P. M. Fernandes, R. Machado, N. Neves, and J. P. Fernandes. 2015. Wildfire patterns and landscape changes in Mediterranean oak woodlands. The Science of the total environment 536:338-352.

54. Guzmán J. 1999. Influence of farming activities in the Iberian Peninsula on the winter habitat use of common crane (Grus grus) in areas of its traditional migratory routes. Agriculture, Ecosystems \& Environment 72:207-214.

55. Herguido E., J. F. Lavado Contador, Á. Gómez Gutiérrez, and S. Schnabel. 2017. Modeling tree loss versus tree recruitment processes in SW Iberian rangelands as influenced by topography and land use and management. Land Degradation \& Development 28:1652-1664.

56. Herguido Sevillano E., J. F. Lavado Contador, M. Pulido, and S. Schnabel. 2017. Spatial patterns of lost and remaining trees in the Iberian wooded rangelands. Applied Geography 87:170-183.

57. Hernández-Esteban A., V. Rolo, M. L. López-Díaz, and G. Moreno. 2019. Long-term implications of sowing legume-rich mixtures for plant diversity of Mediterranean wood pastures. Agriculture, Ecosystems \& Environment 286:106686.

58. Hernández-Lambraño R. E., D. R. La Cruz, and J. Á. Sánchez-Agudo. 2019. Spatial oak decline models to inform conservation planning in the Central-Western Iberian Peninsula. Forest Ecology and Management 441:115-126.

59. Hernando A., R. Tejera, J. Velázquez, and M. V. Núñez. 2010. Quantitatively defining the conservation status of Natura 2000 forest habitats and improving management options for enhancing biodiversity. Biodiversity and Conservation 19:2221-2233.

60. Hevia V., C. P. Carmona, F. M. Azcárate, M. Torralba, P. Alcorlo, R. Ariño, J. Lozano, S. Castro-Cobo, and J. A. González. 2016. Effects of land use on taxonomic and functional diversity. Oecologia 181:959-970.

61. Horrillo A., M. Escribano, F. J. Mesias, A. Elghannam, and P. Gaspar. 2016. Is there a future for organic production in high ecological value ecosystems? Agricultural Systems 143:114-125.

62. Joffre R., J. Vacher, C. los Llanos, and G. Long. 1988. The dehesa: An agrosilvopastoral system of the Mediterranean region with special reference to the Sierra Morena area of Spain. Agroforestry Systems 6:71-96.

63. Leal A. I., R. A. Correia, J. P. Granadeiro, and J. M. Palmeirim. 2011. Impact of cork extraction on birds. Biological Conservation 144:1655-1662. 
64. Leal A. I., R. A. Correia, J. M. Palmeirim, and J. P. Granadeiro. 2013. Does canopy pruning affect foliage-gleaning birds in managed cork oak woodlands? Agroforestry Systems 87:355-363.

65. Leiva M. J., J. M. Mancilla-Leyton, and Á. Martín-Vicente. 2013. Methods to improve the recruitment of holm-oak seedlings in grazed Mediterranean savanna-like ecosystems (dehesas). Annals of Forest Science 70:11-20.

66. Listopad C. M. C. S., M. Köbel, A. Príncipe, P. Gonçalves, and C. Branquinho. 2018. The effect of grazing exclusion over time on structure, biodiversity, and regeneration of high nature value farmland ecosystems in Europe. The Science of the Total Environment 610-611:926-936.

67. López-Carrasco C., A. López-Sánchez, A. San Miguel, and S. Roig. 2015. The effect of tree cover on the biomass and diversity of the herbaceous layer in a Mediterranean dehesa. Grass and Forage Science 70:639-650.

68. López-Sánchez A., R. Dirzo, and S. Roig. 2018. Changes in livestock footprint and tree layer coverage in Mediterranean dehesas. International Journal of Remote Sensing 39:4727-4743.

69. López-Sánchez A., R. Perea, R. Dirzo, and S. Roig. 2016a. Livestock vs. wild ungulate management in the conservation of Mediterranean dehesas. Forest Ecology and Management 362:99-106.

70. López-Sánchez A., A. San Miguel, R. Dirzo, and S. Roig. 2016b. Scattered trees and livestock grazing as keystones organisms for sustainable use and conservation of Mediterranean dehesas. Journal for Nature Conservation 33:58-67.

71. López-Sánchez A., A. San Miguel, C. López-Carrasco, L. Huntsinger, and S. Roig. 2016c. The important role of scattered trees on the herbaceous diversity of a grazed Mediterranean dehesa. Acta Oecologica 76:31-38.

72. Machado R., S. Godinho, N. Guiomar, A. Gil, and J. Pirnat. 2020. Using graph theory to analyse and assess changes in Mediterranean woodland connectivity. Landscape Ecology 35:1291-1308.

73. Maldonado A. D., D. Ramos-López, and P. A. Aguilera. 2019. The role of cultural landscapes in the delivery of provisioning ecosystem services in protected areas. Sustainability 11:2471.

74. Malico I., J. Carrajola, C. P. Gomes, and J. C. Lima. 2016. Biomass residues for energy production and habitat preservation. Case study in a montado area in Southwestern Europe. Journal of Cleaner Production 112:3676-3683.

75. Mancilla Leytón J. M., A. Puerto Marchena, and Á. Martín Vicente. 2017. Land use and land cover dynamics in the dehesa of Sierra Morena Biosphere Reserve (Sierra Norte de Sevilla Natural Park, Spain), 1956-2007. Madera y Bosques 23:133-143.

76. Martin-Díaz P., A. Cortés-Avizanda, D. Serrano, E. Arrondo, J. A. Sánchez-Zapata, and J. A. Donázar. 2020. Rewilding processes shape the use of Mediterranean landscapes by an avian top scavenger. Scientific reports 10:2853.

77. Martín J., and P. Lopez. 2002. The effect of Mediterranean dehesa management on lizard distribution and conservation. Biological Conservation 108:213-219.

78. Martínez-Sastre R., F. Ravera, J. A. González, C. López Santiago, I. Bidegain, and G. Munda. 2017. Mediterranean landscapes under change. Land Use Policy 67:472-486. 
79. Martins H., J. A. Milne, and F. Rego. 2002. Seasonal and spatial variation in the diet of the wild rabbit ( Oryctolagus cuniculus L.) in Portugal. Journal of Zoology 258:395404.

80. Moral F. J., F. J. Rebollo, M. Paniagua, and M. Murillo. 2014. Using an objective and probabilistic model to evaluate the impact of different factors in the dehesa agroforestry ecosystem. Ecological Indicators 46:253-259.

81. Morán-López T., C. L. Alonso, and M. Díaz. 2015. Landscape effects on jay foraging behavior decrease acorn dispersal services in dehesas. Acta Oecologica 69:52-64.

82. Morán-López T., T. Wiegand, J. M. Morales, F. Valladares, and M. Díaz. 2016. Predicting forest management effects on oak-rodent mutualisms. Oikos 125:1445-1457.

83. Moreno-Fernández D., A. Ledo, D. Martín-Benito, I. Cañellas, and G. Gea-Izquierdo. 2019. Negative synergistic effects of land-use legacies and climate drive widespread oak decline in evergreen Mediterranean open woodlands. Forest Ecology and Management 432:884-894.

84. Moreno G., G. Gonzalez-Bornay, F. Pulido, M. L. Lopez-Diaz, M. Bertomeu, E. Juárez, and M. Diaz. 2016. Exploring the causes of high biodiversity of Iberian dehesas. Agroforestry Systems 90:87-105.

85. Mulatu T., R. Bastos, M. Santos, J. P. Sousa, P. M. da Silva, and J. A. Cabral. 2016. Do the passerine traits' dynamic patterns indicate the ecological status of agro-forestry ecosystems? Global Ecology and Conservation 8:154-169.

86. Oksuz D. P., et al. 2020. Increasing biodiversity in wood-pastures by protecting small shrubby patches. Forest Ecology and Management 464:118041.

87. Peco B., A. M. Sánchez, and F. M. Azcárate. 2006. Abandonment in grazing systems. Agriculture, Ecosystems \& Environment 113:284-294.

88. Perea R., A. López-Sánchez, S. Roig, and K. Verheyen. 2016. The use of shrub cover to preserve Mediterranean oak dehesas. Applied Vegetation Science 19:244-253.

89. Pereira M., and A. Rodríguez. 2010. Conservation value of linear woody remnants for two forest carnivores in a Mediterranean agricultural landscape. Journal of Applied Ecology 47:611-620.

90. Pereira P., C. Godinho, I. Roque, A. Marques, M. Branco, and J. E. Rabaça. 2014. Time to rethink the management intensity in a Mediterranean oak woodland. Annals of Forest Science 71:25-32.

91. Pereira P. M., and M. Pires da Fonseca. 2003. Nature vs. nurture. Conservation Ecology 7.

92. Pinto-Correia T., and C. Azeda. 2017. Public policies creating tensions in Montado management models. Land Use Policy 64:76-82.

93. Pinto-Correia T., et al. 2018. Progress in Identifying High Nature Value Montados. Rangeland Ecology \& Management 71:612-625.

94. Pinto-Correia T., H. Menezes, and L. F. Barroso. 2014. The landscape as an asset in Southern European fragile agricultural systems. Landscape Research 39:205-217.

95. Pinto-Correia T., J. Muñoz-Rojas, M. H. Thorsøe, and E. B. Noe. 2019. Governance discourses reflecting tensions in a multifunctional land use system in decay; tradition versus modernity in the Portuguese montado. Sustainability 11:3363.

96. Pinto R., P. Antunes, S. Blumentrath, R. Brouwer, P. Clemente, and R. Santos. 2019. Spatial modelling of biodiversity conservation priorities in Portugal's montado ecosystem using Marxan with Zones. Environmental Conservation 46:251-260. 
97. Plieninger T. 2006. Habitat loss, Fragmentation, and Alteration - Quantifying the Impactof Land-use Changes on a Spanish Dehesa Landscape by Use of Aerial Photography and GIS. Landscape Ecology 21:91-105.

98. Plieninger T. 2007. Compatibility of livestock grazing with stand regeneration in Mediterranean holm oak parklands. Journal for Nature Conservation 15:1-9.

99. Plieninger T., J. Modolell y Mainou, and W. Konold. 2004. Land manager attitudes toward management, regeneration, and conservation of Spanish holm oak savannas (dehesas). Landscape and Urban Planning 66:185-198.

100. Plieninger T., F. J. Pulido, and W. Konold. 2003. Effects of land-use history on size structure of holm oak stands in Spanish dehesas. Environmental Conservation 30:61-70.

101. Plieninger T., and C. Wilbrand. 2001. Land use, biodiversity conservation, and rural development in the dehesas of Cuatro Lugares, Spain. Agroforestry Systems 51:23-34.

102. Pulido F., E. García, J. J. Obrador, and G. Moreno. 2010. Multiple pathways for tree regeneration in anthropogenic savannas. Journal of Applied Ecology 47:1272-1281.

103. Pulido F. J., M. Díaz, and S. J. Hidalgo de Trucios. 2001. Size structure and regeneration of Spanish holm oak Quercus ilex forests and dehesas. Forest Ecology and Management 146:1-13.

104. Ramírez-Hernández A., E. Micó, M. d. l. Á. Marcos-García, H. Brustel, and E. Galante. 2014. The "dehesa", a key ecosystem in maintaining the diversity of Mediterranean saproxylic insects (Coleoptera and Diptera. Biodiversity and Conservation 23:20692086.

105. Ramírez J. A., and M. Díaz. 2008. The role of temporal shrub encroachment for the maintenance of Spanish holm oak Quercus ilex dehesas. Forest Ecology and Management 255:1976-1983.

106. Rolo V., T. Plieninger, G. Moreno, and M. Zobel. 2013. Facilitation of holm oak recruitment through two contrasted shrubs species in Mediterranean grazed woodlands. Journal of Vegetation Science 24:344-355.

107. Rosalino L. M., J. d. Rosário, and M. Santos-Reis. 2009. The role of habitat patches on mammalian diversity in cork oak agroforestry systems. Acta Oecologica 35:507-512.

108. Rosalino L. M., M. J. Santos, P. Beier, and M. Santos-Reis. 2008. Eurasian badger habitat selection in Mediterranean environments. Mammalian Biology 73:189-198.

109. Russo D., D. Almenar, J. Aihartza, U. Goiti, E. Salsamendi, and I. Garin. 2005. Habitat selection in sympatric Rhinolophus mehelyi and R. euryale (Mammalia. Journal of Zoology 266:327-332.

110. Sánchez M., M. Blas, and G. Rengifo. 2019. The dehesas of Extremadura, Spain. Forests 10:620.

111. Santos-Silva C., A. Gonçalves, and R. Louro. 2011. Canopy cover influence on macrofungal richness and sporocarp production in montado ecosystems. Agroforestry Systems 82:149-159.

112. Santos M. J., and P. Beier. 2008. Habitat selection by European badgers at multiple spatial scales in Portuguese Mediterranean ecosystems. Wildlife Research 35:835.

113. Santos R., P. Clemente, R. Brouwer, P. Antunes, and R. Pinto. 2015. Landowner preferences for agri-environmental agreements to conserve the montado ecosystem in Portugal. Ecological Economics 118:159-167. 
114. Simões M. P., A. F. Belo, M. Fernandes, and M. Madeira. 2016. Regeneration patterns of Quercus suber according to montado management systems. Agroforestry Systems 90:107-115.

115. Simonson W. D., H. D. Allen, E. Parham, E. Basto e Santos, and P. Hotham. 2018. Modelling biodiversity trends in the montado (wood pasture) landscapes of the Alentejo, Portugal. Landscape Ecology 33:811-827.

116. Slancarova J., P. Garcia-Pereira, Z. F. Fric, H. Romo, and E. Garcia-Barros. 2015. Butterflies in Portuguese 'montados'. Journal of Insect Conservation 19:823-836.

117. Smit C., M. Díaz, and P. Jansen. 2009. Establishment limitation of holm oak (Quercus ilex subsp. ballota (Desf.) Samp.) in a Mediterranean savanna — forest ecosystem. Annals of Forest Science 66:511.

118. Smit C., J. Ouden, and M. Díaz. 2008. Facilitation of Quercus ilex recruitment by shrubs in Mediterranean open woodlands. Journal of Vegetation Science 19:193-200.

119. Soares C., A. Príncipe, M. Köbel, A. Nunes, C. Branquinho, and P. Pinho. 2018. Tracking tree canopy cover changes in space and time in High Nature Value Farmland to prioritize reforestation efforts. International Journal of Remote Sensing 39:47144726.

120. Surová D., and T. Pinto-Correia. 2008. Landscape preferences in the cork oak Montado region of Alentejo, southern Portugal. Landscape Research 33:311-330.

121. Surová D., and T. Pinto-Correia. 2009. Use and assessment of the 'new' rural functions by land users and landowners of the montado in Southern Portugal. Outlook on Agriculture 38:189-194.

122. Surová D., and T. Pinto-Correia. 2016. A landscape menu to please them all. Land Use Policy 54:355-365.

123. Surová D., T. Pinto-Correia, and R. Marušák. 2014. Visual complexity and the montado do matter. Annals of Forest Science 71:15-24.

124. Surová D., F. Ravera, N. Guiomar, R. Martínez Sastre, and T. Pinto-Correia. 2018. Contributions of Iberian silvo-pastoral landscapes to the well-being of contemporary society. Rangeland Ecology \& Management 71:560-570.

125. Toro-Mujica P. M., C. Aguilar, R. Vera, C. Barba, J. Rivas, and A. García-Martínez. 2015. Changes in the pastoral sheep systems of semi-arid Mediterranean areas. Spanish Journal of Agricultural Research 13:e0102.

126. Torralba M., E. Oteros-Rozas, G. Moreno, and T. Plieninger. 2018. Exploring the role of management in the coproduction of ecosystem services from Spanish wooded rangelands. Rangeland Ecology \& Management 71:549-559.

127. Torres I., I. R. Urbieta, and J. M. Moreno. 2015. Vegetation and soil seed bank relationships across microhabitats in an abandoned Quercus suber parkland under simulated fire. Écoscience 19:1-10.

128. van Doorn A. M., and M. M. Bakker. 2007. The destination of arable land in a marginal agricultural landscape in South Portugal. Landscape Ecology 22:1073-1087. 